\title{
What Drives the Commonality between Credit Default Swap Spread Changes?
}

\author{
Mike Anderson*
}

\begin{abstract}
This paper documents an increase in the comovement between credit default swap (CDS) spread changes during the 2007-2009 crisis and investigates the source of that increase. One possible explanation is that comovement increased because fundamental values became more correlated. However, I find that changes in fundamentals account for only $23 \%$ of the increase in covariance. The remaining increase is attributed to changes in liquidity and the market price of default risk. In contrast, counterparty risk played an insignificant role. Although both contributed, the increase in covariance was driven more by variation in exposures than factor variance-covariance.
\end{abstract}

\section{Introduction}

Diversification of risk in financial markets is limited by the level of commonality between asset price movements. Over the past decade, explosive growth in the use of credit default swap (CDS) contracts led many investors, particularly large financial institutions, to bear exposure to the CDS market. ${ }^{1}$ As a result, the comovement between CDS spread changes is fundamental to evaluating the risk that an active CDS market poses to the financial system.

Despite its importance, surprisingly little is known about what drives comovement, especially in times of economic turmoil. Research efforts have focused more on the information content of CDS spreads (see Blanco, Brennan, and Marsh (2005), Longstaff (2010), Bongaerts, de Jong, and Driessen (2011), and

*Anderson (corresponding author), mander19@ gmu.edu, School of Business, George Mason University. I am grateful for helpful discussion and suggestions from Joost Driessen and Spencer Martin (the referees) and from Jack Bao, Hendrik Bessembinder (the editor), Phil Davies, Darrell Duffie, Kewei Hou, Andrew Karolyi, Rose Liao, Bernadette Minton, Taylor Nadauld, Alex Philipov, Tim Scholl, Ken Singleton, René Stulz, Jennifer Sustersic, Jérôme Taillard, and Scott Yonker. I thank seminar participants at Ohio State University, the U.S. Securities and Exchange Commission, Dimensional Fund Advisors, the University of New South Wales, the Federal Reserve Board, George Mason University, and George Washington University. I also thank the Dice Center for research support.

${ }^{1}$ According to the Office of the Comptroller of the Currency, the 20 largest commercial banks were also the most active in trading CDS protection in 2007. 
Arora, Gandhi, and Longstaff (2012)) than on comovement, which has mainly been studied under normal economic conditions (see Jorion and Zhang (2007), (2009), Acharya, Schaefer, and Zhang (2015), and Ericsson, Jacobs, and Oviedo (2009)). Therefore, how and why comovement changes under economic distress remains an open question. This paper addresses that gap by documenting an increase in the commonality between corporate single-name CDS spread changes during the 2007-2009 crisis and investigates whether that increase was driven by fundamental credit risk or noncredit factors, including liquidity, counterparty risk, and the default risk premium.

An increase in the comovement between CDS spread changes is important because it robs investors of their ability to diversify when diversification is most needed. In the CDS market, this can directly impact the financial sector's ability to function. Major players in the CDS market are often systemically important financial institutions that operate with low capital buffers. As a result, increased commonality can lead to forced deleveraging as institutions adjust their balance sheets to tolerate a higher level of risk. Therefore, the escalation in comovement documented later in the paper likely increased the probability that investors with exposure to the CDS market would need to raise capital or shed risk under adverse economic conditions.

At the same time, growing institutional holdings of AAA tranches of collateralized debt obligations (CDOs) introduced an additional layer of risk. These assets decrease in value with correlation and are often priced using models that rely on the historical correlations between single-name CDS spreads. As a result, an increase in commonality may lead to write-downs that can further inhibit the financial sector's ability to bear risk. A natural question, in light of this discussion, is whether the increase in comovement and resulting instability was driven by a joint deterioration in credit quality or by noncredit factors that can arise in the CDS market.

To address this question, I obtain daily spreads for 159 liquid investmentgrade corporate single-name CDS contracts from Dec. 23, 2005, to Mar. 9, 2009. ${ }^{2}$ As a first step, I document an increase in the comovement between firm-level CDS spread changes in the crisis (after July 30, 2007) using simple measures of association.

Next, I decompose covariance into fundamental and excess components to better understand why comovement increased. For this analysis, I aggregate to quintile portfolios based on Moody's KMV expected default frequency (EDF) measure, which allows for a more precise decomposition. Relying on prior research, I separate fundamental and excess covariance using a linear factor model with covariates implied by Merton (1974) (see Collin-Dufresne, Goldstein, and Martin (2001), Ericsson et al. (2009)). Within the reduced dimension of the portfolio analysis, the model is estimated in a system of seemingly unrelated regressions (SURs).

\footnotetext{
${ }^{2}$ These contracts are included in the CDS North American Investment Grade Index (CDX.NA.IG) rolls 8-12. The CDS market rebounded on Mar. 9, 2009. Dec. 23, 2005, was chosen to yield balanced panels.
} 
I find that the covariance between portfolio CDS spread changes increased 70 -fold over its precrisis level on average, resulting in a $\$ 2.5 \mathrm{M}$ increase in valueat-risk (VaR) for a portfolio of $60 \mathrm{CDS}$ contracts. However, only $23 \%$ of the increase in covariance relates to fundamentals. The remainder can largely be attributed to changes in liquidity and the default risk premium, which account for an additional $10 \%$ and $18 \%$ of the increase, respectively. In contrast, I find no evidence that counterparty risk increased comovement. ${ }^{3}$

Finally, I investigate the importance of time-varying parameters. This analysis evaluates the relative performance, based on covariance mean-squared error, of each variable specification with constant, quarterly, and monthly betas (see Bekaert, Hodrick, and Zhang (2009)). Not surprisingly, I find that controlling for changes in fundamentals, liquidity, and the default risk premium with monthly time-varying betas best characterizes the sample covariance structure under economic distress. ${ }^{4}$ With time-varying parameters, the model captures $66 \%$ of the increase in covariance compared to $45 \%$ with constant parameters. Additionally, it explains $\$ 40,000$ of the $\$ 47,500$ sample VaR in the crisis per $\$ 10 \mathrm{M}$ notional. Further analysis shows that the increase in covariance is related more to the time variation in betas than factor variance-covariance.

Ultimately, $34 \%$ of the increase in covariance is left unexplained. However, Figure 2 shows that this is directly related to the Lehman Brothers' failure and resolves within 6 months of the event.

Overall, these results enhance our understanding of the CDS market. They are important for future regulation, portfolio allocation, and pricing of credit derivatives. For instance, Basel III introduced specific capital charges for correlation trading portfolios and "stressed" VaR. Therefore, a better understanding of the sources that increase commonality may help implement and refine these new standards. Moreover, the dynamic nature of covariance illustrated herein and contributions from noncredit-related factors are important considerations for informed portfolio allocation decisions.

This paper contributes to a small but growing string of literature on the commonality in CDS spreads. Early work focused on dependence under normal economic conditions. Researchers identified mechanisms that link CDS spreads through the expected future cash flows of reference firms and showed that comovement was largely related to observed economic variables (see Jorion and Zhang (2007), (2009), Ericsson et al. (2009), Acharya et al. (2015), Berndt et al. (2008), Kim, Loretan, and Remolona (2010), and Azizpour, Giesecke, and Kim (2011)), whereas others argued that a significant fraction of correlations could be attributed to contagion (see Pu and Zhao (2012)). More recently, Christoffersen, Jacobs, Jin, and Langlois (2016) use a dynamic copula approach to illustrate a

${ }^{3}$ Tests for liquidity employ several proxies to capture systematic liquidity, transaction costs, bond liquidity, and funding liquidity. I follow the panel regression methodology outlined by Berndt, Douglas, Duffie, Ferguson, and Schranz (2008) to obtain a time-varying measure of the default risk premium. Counterparty risk proxies include various measures of dealers' credit quality. This analysis holds exposures and factor variance-covariance constant over the precrisis and crisis subperiods.

${ }^{4}$ Covariance mean-squared error compares the model-implied to sample covariance each month. This allows for monthly variation in factor variance-covariance. The constant-beta model allows for a one-time change in betas at the onset of the crisis. 
loss in diversification benefit after 2008. However, they provide little insight into the economic mechanism. To my knowledge, this is the first study to document an increase in the comovement between CDS spread changes in response to a change in economic conditions and investigate the factors that drive that change.

The paper proceeds as follows: Section II describes the data. Section III shows that comovement increased and explores the contribution from fundamentals. In Sections IV, V, and VI, respectively, I investigate the impact of liquidity, counterparty risk, and the default risk premium on the change in covariance. Section VII introduces time-varying parameters and discusses their impact on covariance. Section VIII concludes the paper.

\section{Data and Sample Characteristics}

I obtain daily end-of-day dealer-aggregate mid-quotes on 5-year contracts that trade under the North American convention from Credit Market Analysis (CMA). The 5-year maturity is widely considered the most liquid and is standard in the academic literature. Contracts that trade under the North American convention are standardized, which ensures that premiums reference the same contract specification (see Casey and Price (2009)). Finally, I use daily data to better capture the high frequency of events that transpired over the crisis. This has the added benefit of making the results more applicable to VaR models commonly used to determine capital requirements at financial institutions.

The sample includes daily spreads for constituents of the CDX.NA.IG index rolls 8-12 from Dec. 23, 2005, to Mar. 9, 2009. This index is constructed every 6 months to include 125 investment-grade contracts identified by dealer surveys as the most liquid on the market. My final sample consists of 125,752 firm-day observations and covers 159 reference entities. I then split the data into balanced precrisis and crisis subperiods on July 31, 2007.

The first four rows of Panel A in Table 1 illustrate a stark shift in the CDS market beginning in 2007. On average, CDS spreads increased from 37 basis points (bps) to a high of $367 \mathrm{bps}$ in 2008. The mean and volatility of CDS spread changes increased as well, most likely in response to heightened economic uncertainty.

The remainder of Panel A of Table 1 reports average market-to-book ratio, cash holdings, profitability, total assets, book leverage, and size, which Campbell, Hilscher, and Szilagyi (2008) show are important determinates of credit quality. To better understand how this sample relates to other commonly studied firms, I compare the average firm in my sample to that of the Center for Research in Security Prices (CRSP)/Compustat Universe. Results suggest that, on average, these firms are not remarkably levered or profitable, nor do they have extraordinary growth prospects when compared with firms in the CRSP/Compustat universe. In contrast, sample firms are relatively large cash-rich entities with high total asset values.

Panels B and C of Table 1, respectively, show the distribution of Moody's KMV EDF and Standard \& Poor's (S\&P) long-term issuer credit ratings by year. 
In Panel A of Table 1, rows 1-4 present the mean and volatility of CDS spread levels and changes over all contracts in the sample by year. Rows 1-6 present the average firm characteristics in each year. Accounting data are taken from Compustat on Dec. 31 or the nearest date not exceeding 6 months pre/post. I calculate firm characteristics as follows using Compustat notation: BOOK LEVERAGE $=($ AT $-(A T-L T-P S T L K+T X D I T C+D C V T)) / A T, M A R K E T$ TO BOOK $=$ $($ CSHO $\times$ PRCC_F + AT - (AT - LT - PSTLK+TXDITC+DCVT))/AT (see Baker and Wurgler (2002)), PROFITABILITY= $\mathrm{NI} / \mathrm{AT}, \mathrm{CASH}=\mathrm{CH}$, TOTAL_ASSETS $=$ AT, and MARKET_CAPITALIZATION $=\mathrm{CSHO} \times \mathrm{PRCC}$. F. CASH, TOTAL_ASSETS, and MARKET_CAPITALIZATION are reported in \$billions. Sample means that differ significantly at the $1 \%$ level from the average CRSP/Compustat merged firm are reported in bold. Panel B reports the distribution of EDF, in percentages, over sample firms in each year. Panel $\mathrm{C}$ reports the distribution of annual (first monthly observation) S\&P long-term issuer credit ratings when available.

\begin{tabular}{|c|c|c|c|c|}
\hline & 2006 & 2007 & 2008 & 2009 \\
\hline \multicolumn{5}{|c|}{ Panel A. Sample Firm Characteristics } \\
\hline CDS & 37.72 & 58.38 & 367.39 & 337.64 \\
\hline$\sigma \mathrm{CDS}$ & 25.04 & 111.61 & 2451.75 & 584.09 \\
\hline$\triangle \mathrm{CDS}$ & -0.04 & 0.32 & 3.14 & -1.02 \\
\hline$\sigma \Delta \mathrm{CDS}$ & 1.69 & 19.16 & 288.86 & 53.63 \\
\hline BOOK_LEVERAGE & 0.59 & 0.60 & 0.66 & 0.64 \\
\hline PROFITABILITY & 0.06 & 0.04 & 0.00 & 0.02 \\
\hline MARKET_TO_BOOK & 1.57 & 1.47 & 1.23 & 1.33 \\
\hline $\mathrm{CASH}$ & 1.83 & 2.01 & 3.02 & 3.36 \\
\hline TOTAL_ASSETS & 66.93 & 71.00 & 71.45 & 72.32 \\
\hline MARKËT_CAP & 35.06 & 33.60 & 21.25 & 24.83 \\
\hline \multicolumn{5}{|c|}{ Panel B. EDF Distributions (\%) } \\
\hline 99th & 0.74 & 1.18 & 12.32 & 22.23 \\
\hline 75th & 0.14 & 0.12 & 0.45 & 2.29 \\
\hline 50th & 0.08 & 0.07 & 0.18 & 0.89 \\
\hline 25th & 0.04 & 0.04 & 0.09 & 0.35 \\
\hline $1 s t$ & 0.01 & 0.01 & 0.02 & 0.06 \\
\hline
\end{tabular}

Panel C. S\&P Long-Term Issuer Credit Ratings

\begin{tabular}{lrrrr} 
AAA & 3 & 3 & 2 & 1 \\
AA+ & 0 & 0 & 2 & 2 \\
AA & 4 & 4 & 2 & 0 \\
AA- & 1 & 0 & 11 & 2 \\
A+ & 9 & 10 & 20 & 1 \\
A & 25 & 23 & 20 & 18 \\
A- & 20 & 20 & 30 & 29 \\
BBB+ & 31 & 32 & 27 & 21 \\
BBB & 33 & 36 & 6 & 19 \\
BBB- & 16 & 15 & 142 & 16 \\
<BB- & 3 & 1 & 142 \\
Total & 145 & 144 & \\
\hline
\end{tabular}

The rating distributions are centered between $\mathrm{BBB}$ and $\mathrm{BBB}+$, with a slight shift toward speculative grade in 2009. ${ }^{5}$

\section{Comovement}

In this section, I document an increase in the comovement between CDS spread changes during the crisis and investigate its relationship to fundamental credit risk. The discussion is split into four subsections: The first tests for an increase in comovement. The second decomposes covariance using a linear factor model. The third describes the fundamental variable specification. Finally, the fourth subsection reviews the results.

${ }^{5}$ Long-term issuer credit ratings can drop below investment grade. This is because the CDX.NA.IG index is constructed using a single investment-grade bond from each issuer. In contrast, $\mathrm{S} \& \mathrm{P}$ issuer ratings evaluate the credit quality of the company. 


\section{A. Measuring Comovement}

To establish that the comovement between daily firm-level CDS spread changes increased in the crisis, I sort firms into quintiles based on their EDF on July 31,2007 , and evaluate the change in: i) intraclass correlation, ii) the average Spearman's correlation, and iii) the average fraction of firms with CDS spreads that moved in the same direction each week (FRAC) (see Morck, Yeung, and Yu (2000)).

These results, reported in Table 2, show that comovement increased within the full sample and within each EDF-sorted subsample. ${ }^{6}$ Panels A and B, respectively, record a significant increase, at the $1 \%$ level, in both intraclass correlation and average Spearman's correlation during the crisis. Moreover, FRAC increased from approximately $65 \%$ to $75 \%$, which was a significant increase at the $1 \%$ level across all subsamples.

Finally, additional evidence of a shift in comovement is provided in Figure 1, which graphs the cross-sectional densities of pairwise correlations over the precrisis and crisis subperiods.

\section{TABLE 2}

\section{Changes in Comovement}

Intraclass correlation, average Pearson's correlation, and the average fraction of firms with CDS spreads that moved in the same direction each week (FRAC) are reported in Panels A, B, and C of Table 2, respectively. Columns 2 and 3 show the precrisis and crisis levels, respectively (pre/post July 31,2007 ). Columns 4 and 5 report the change and associated $p$-values, respectively. I test the change in intraclass correlation using the modified Fisher $Z$-test described by Donner and Zou (2002). The test is sensitive to changes in variance, so I standardized CDS spread changes in the precrisis and crisis subperiods. The significance of the change in average Spearman's correlations is evaluated using Kendall's concordance coefficient $(W)$, a simple transformation of the average Spearman's correlation (see Schucany and Frawley (1973)). I calculate FRAC over each week of the sample period. Assuming independent weekly observations, I use the asymptotic distribution developed by Morck et al. (2000) to test the change. Note that FRAC is bound between 0.5 and 1 and will naturally produce higher values. Tests of intraclass correlation and average Spearman's correlation are sensitive to missing values, so I require contracts to have at least 1 year of data on either side of the crisis, which slightly reduces the number of contracts. ${ }^{*}, * *$, and ${ }^{* * *}$ indicate statistical significance at the $10 \%, 5 \%$, and $1 \%$ levels, respectively. $p$-values from a nonparametric bootstrap test are provided in parentheses.

$\underline{\text { No. of Firms }} \quad \underline{\text { Precrisis }} \quad \underline{\text { Crisis }} \quad \underline{\text { Difference }} \quad \underline{p \text {-Value }}$

Panel A. Intraclass Correlation

\begin{tabular}{|c|c|c|c|c|c|}
\hline All & 153 & 0.17 & 0.61 & $0.44^{* * *}$ & $0.00(0.00)$ \\
\hline 1 (Low EDF) & 32 & 0.19 & 0.41 & $0.22^{\star * *}$ & $0.00(0.00)$ \\
\hline 2 & 33 & 0.16 & 0.71 & $0.55^{\text {*** }}$ & $0.00(0.00)$ \\
\hline 3 & 25 & 0.17 & 0.41 & $0.24^{\star \star *}$ & $0.00(0.00)$ \\
\hline 4 & 32 & 0.22 & 0.34 & $0.12^{\star \star \star *}$ & $0.00(0.00)$ \\
\hline 5 (High EDF) & 31 & 0.26 & 0.34 & $0.08^{* \star *}$ & $0.01(0.01)$ \\
\hline
\end{tabular}

Panel B. Average Spearman's Correlation

\begin{tabular}{|c|c|c|c|c|c|}
\hline All & 153 & 0.19 & 0.46 & $0.27^{\star \star \star}$ & $0.00(0.00)$ \\
\hline 1 (Low EDF) & 32 & 0.16 & 0.50 & $0.34^{* * *}$ & $0.00(0.00)$ \\
\hline 2 & 33 & 0.19 & 0.48 & $0.29^{\star \star \star}$ & $0.00(0.00)$ \\
\hline 3 & 25 & 0.22 & 0.46 & $0.24^{\star \star *}$ & $0.00(0.00)$ \\
\hline 4 & 32 & 0.19 & 0.43 & $0.24^{\star \star \star}$ & $0.00(0.00)$ \\
\hline 5 (High EDF) & 31 & 0.25 & 0.43 & $0.18^{\star \star \star}$ & $0.00(0.00)$ \\
\hline \multicolumn{6}{|c|}{ Panel C. Comovement Fraction } \\
\hline All & 159 & 0.66 & 0.75 & $0.09^{\star \star \star}$ & $0.00(0.00)$ \\
\hline 1 (Low EDF) & 32 & 0.64 & 0.77 & $0.13^{\star \star \star}$ & $0.00(0.00)$ \\
\hline 2 & 34 & 0.66 & 0.76 & $0.10^{\star \star \star}$ & $0.00(0.00)$ \\
\hline 3 & 30 & 0.69 & 0.75 & $0.06^{* \star *}$ & $0.00(0.00)$ \\
\hline 4 & 32 & 0.67 & 0.76 & $0.09^{\star \star \star}$ & $0.00(0.00)$ \\
\hline 5 (High EDF) & 31 & 0.69 & 0.76 & $0.07^{\star \star \star}$ & $0.00(0.00)$ \\
\hline
\end{tabular}

\footnotetext{
${ }^{6}$ Intraclass correlation is subject to distributional assumptions that are relaxed in the nonparametric tests for average Spearman's correlation and FRAC.
} 


\section{FIGURE 1}

\section{Distributions of Pairwise Correlation Coefficients}

Pairwise correlations for all possible firm pairs are calculated prior to and during the crisis. In gray (right) is the crosssectional density of pairwise correlation during the crisis, and in black (left) is the cross-sectional density of pairwise correlation prior to the crisis. A Kolmogorov-Smirnov test confirms that the distributions differ significantly at the $1 \%$ level.

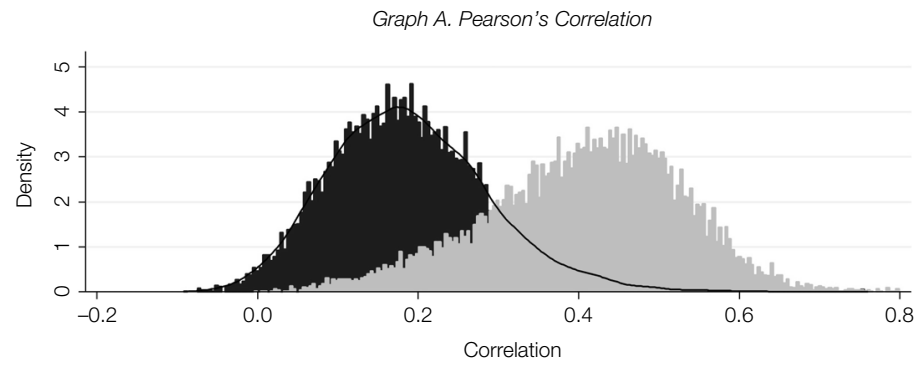

Graph B. Spearman's Correlation

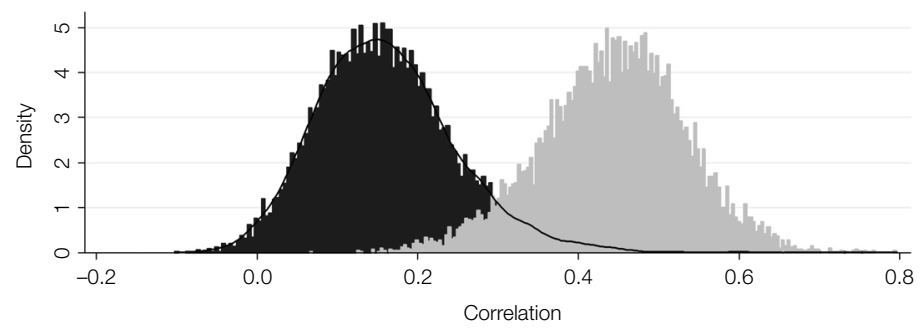

\section{B. Decomposing Comovement}

I begin the decomposition by aggregating to quintile portfolios, which reduces some of the noise in firm-level data. These portfolios are rebalanced on the last day of each month according to the prevailing EDF. The portfolio spread, on each day of the subsequent month, is simply the equal-weighted average spread over contracts in the quintile. $^{7}$

Following Bekaert, Harvey, and Ng (2005), I employ a linear factor model to characterize the comovement between CDS spread changes. In this setting, the sample covariance can be decomposed into model-implied (fundamental) and excess covariance, as follows:

(1) $\mathrm{E}_{\tau}\left[\Delta \mathrm{CDS} \Delta \mathrm{CDS}^{\prime}\right]=\mathrm{E}_{\tau}\left[\left(\beta_{\tau} \mathrm{F}^{\prime}+\epsilon\right)\left(\beta_{\tau} \mathrm{F}^{\prime}+\epsilon\right)^{\prime}\right]=\beta_{\tau} \mathrm{E}_{\tau}\left[\mathrm{F}^{\prime} \mathrm{F}\right] \beta_{\tau}^{\prime}+\mathrm{E}_{\tau}\left[\epsilon \epsilon^{\prime}\right]$,

where $\triangle \mathrm{CDS}$ is an $\mathrm{M} \times 1$ vector of portfolio $\mathrm{CDS}$ spread changes, $\beta_{\tau}$ is an $\mathrm{M} \times \mathrm{K}$ matrix of factor exposures, $\mathrm{F}$ is a $1 \times \mathrm{K}$ vector of factors, and $\epsilon$ is a $\mathrm{M} \times$ 1 vector of residuals. The subscript $\tau=$ \{precrisis, crisis $\}$ in the baseline analysis. I refer to $\mathrm{E}_{\tau}\left[\mathrm{F}^{\prime} \mathrm{F}\right]$ as $\Sigma_{\tau}$ for the remainder of the paper.

${ }^{7}$ I use the median industry EDF (Fama and French 5 and financials) to classify firms when firmlevel EDF is unavailable. Additionally, I drop outliers ( 2 times the interquartile range) from the average on each day to reduce idiosyncratic effects. 
Equation (1) implies that, all else equal, comovement can increase for three reasons: i) an increase in exposure(s) to a common factor, ii) an increase in $\Sigma_{\tau}$, and iii) an increase in covariance between unexplained CDS spread changes.

To operationalize the decomposition, I estimate the factor model in a system of SURs over each time period using the feasible generalized least squares (FGLS) approach (see Kallberg and Pasquariello (2008)). This analysis employs a coarse definition of $\tau$, which is useful for investigating the relative impact that different economic factors have on the change in covariance. However, it may be overly restrictive. Therefore, I refine $\tau$ in Section VII to explore the effect of time-varying parameters.

Using the current framework, I test for a change in beta using cross-equation constraints. This lends insight into whether covariance increased due to risk (beta) or $\Sigma_{\tau}$. Importantly, rolling the estimation over the precrisis and crisis subperiods implicitly controls for changes in factor variance-covariance as well as changes in residual covariance.

For a more comprehensive analysis on the joint effect of changes in beta and $\Sigma_{\tau}$ on the change in covariance, I calculate the percentage of the change in covariance captured by the model: $(\mathrm{COVR})=\left(\Delta \hat{\beta}_{i, \tau} \hat{\Sigma}_{\tau} \hat{\beta}_{j, \tau}\right) / \Delta \widehat{\operatorname{cov}}(i, j)_{\tau}$. In this case, significance is evaluated using a simple nonparametric bootstrap with replacement and percentile confidence intervals to account for asymmetry in the empirical distribution.

\section{Factor Model Specification}

My baseline (fundamental) specification follows the work of CollinDufresne et al. (2001), who investigate the determinants of credit spread changes implied by Merton (1974). ${ }^{8}$ In addition, I include systematic proxies that may provide useful information about default probabilities and expected losses in default (see Allen and Saunders (2003)). The final specification is as follows:

$$
\begin{aligned}
\Delta \mathrm{CDS}= & \alpha+\beta_{1, \tau}(\Delta \mathrm{RF} 3 \mathrm{M})+\beta_{2, \tau}(\Delta \mathrm{SLOPE})+\beta_{3, \tau}(\Delta \mathrm{SPVOL}) \\
& +\beta_{4, \tau}(\mathrm{SP} 500)+\beta_{5, \tau}(\mathrm{HB})+\beta_{6, \tau}(\Delta \mathrm{DEF})+\beta_{7, \tau}(\mathrm{SMB}) \\
& +\beta_{8, \tau}(\mathrm{HML})+\beta_{9, \tau}(\mathrm{PORTRET})+\beta_{10, \tau}(\Delta \mathrm{PORTVOL})+\epsilon,
\end{aligned}
$$

where RF3M is the 3-month risk-free rate, SLOPE measures the slope of the yield curve, SPVOL is the generalized autoregressive conditional heteroskedasticity (GARCH) volatility of the S\&P 500 index return, SP500 is the S\&P 500 index return, and HB is the return for an index of U.S. home builders. DEF is the yield difference between Moody's Baa and Aaa seasoned bond indices. SMB and HML are the small cap and value premiums, respectively. PORTRET is the equalweighted equity return for the EDF-sorted quintile portfolio. Finally, PORTVOL is the GARCH volatility of PORTRET. Consistent with Collin-Dufresne et al. (2001), $\Delta$ in equation (1) denotes the daily change. Further details on the construction and interpretation of each variable are provided in the Appendix.

\footnotetext{
${ }^{8}$ Collin-Dufresne et al. (2001) argue that the model does not fully capture the common component in bond yield spreads. However, Ericsson et al. (2009) show that the residual common component from a similar model is greatly reduced when using CDS spreads. Moreover, evidence suggests that the underperformance of structural form models is largely due to noncredit-related factors (see Schaefer and Strebulaev (2008), Bao and Pan (2013)).
} 


\section{Factor Model Results}

Results of the precrisis factor model estimation are reported in the upper half of Panel A in Table 3. Not surprisingly, SP500, $\triangle \mathrm{RF} 3 \mathrm{M}, \triangle \mathrm{SLOPE}$, and $\triangle \mathrm{DEF}$ are significant with the appropriate sign across most CDS portfolios. Consistent with a state variable interpretation, CDS spread changes across all portfolios are negatively related to the value premium. In contrast, portfolio equity returns and changes in equity volatility are not. However, $\triangle$ PORTVOL becomes positive and significant across most portfolios once $\triangle$ SPVOL is omitted, which is consistent with Campbell and Taksler (2003).

Several interesting results arise from the tests for a change in beta reported in the lower half of Panel $A$ in Table 3. First, exposures to SP500, $\triangle R F 3 M$, and HB increased monotonically across EDF-sorted portfolios. This suggests that increased credit risk specifically linked to changes in macroeconomic conditions, the risk-neutral drift, and housing market conditions increased the covariance between all portfolio pairs in the crisis. Moreover, the magnitude of the increase was more pronounced for portfolios with higher credit risk.

Second, exposure to HML became insignificant across all portfolios during the crisis, which may represent a decoupling of the CDS and equity market over this time period. Third, the change in exposure to $\triangle \mathrm{DEF}$ is insignificant across all portfolios. This supports the view that DEF is a coarse measure of credit market conditions rather than a precise proxy for the default risk premium (see Gilchrist and Zakrajsek (2012)). ${ }^{9}$ Finally, $R^{2}$ values suggest that the model captures approximately $25 \%$ of the variation in daily change in CDS.

These results indicate that an increase in exposures to systematic credit risk factors contributed to the increase in sample covariance. However, the change in $\Sigma_{\tau}$ also played an important role. Panel B of Table 3 shows that under the current model specification, a joint one-time shift in $\beta_{\tau}$ and $\Sigma_{\tau}$ captures $23 \%$ of the increase in sample covariance. This compares with $10 \%$ (unreported) when $\Sigma_{\tau}$ is held constant over the full sample period. ${ }^{10}$

Next, I explore the economic impact of the change in covariance. For each equal-weighted pairwise combination of EDF-sorted portfolios, I compare the 99\% VaR in the crisis to its counterfactual, which holds the covariance structure constant at its precrisis level. ${ }^{11}$ These results show that the change in sample

\footnotetext{
${ }^{9}$ If DEF precisely measured the default risk premium, this result would imply that default probabilities did not change significantly in the crisis.

${ }^{10}$ The average covariance between residual CDS spread changes prior to and during the crisis is 0.20 and 14.56, respectively. Box $\mathrm{M}$ tests show that covariance is significant at the $1 \%$ level in all cases, which is consistent with prior work. Further analysis shows that $23 \%$ and $42 \%$ of the time-series variation in firm-level residuals is captured by the first principal component prior to and during the crisis, respectively. These numbers increase to approximately $80 \%$ and $90 \%$, respectively, for creditbased portfolios. Again, this confirms the existing result that commonality in firm-level residuals is relatively modest but increases with the level of portfolio diversification (see Collin-Dufresne et al. (2001), Ericsson et al. (2009), and Duffie, Eckner, Horel, and Saita (2009)).

${ }^{11}$ To calculate VaR, I sum the present value of cash flows generated by selling a $\$ 10 \mathrm{M}$ contract on day $t$ and buying it back on day $t+1$. This yields 5 years of quarterly payments $(\Delta \operatorname{CDS} / 4 \times$ $\$ 10 \mathrm{M})$ that I discount at the risk-free rate. Next, I use the mean and variance from the time series of summed discounted cash flows to calculate VaR. Finally, I compare the crisis VaR to the counterfactual: $\mu_{\text {crisis }}+2.33 \sigma_{\text {crisis }}-\left(\mu_{\text {crisis }}+2.33 \sigma_{\text {precrisis }}\right)$. This method assumes that the physical probability of
} 


\section{TABLE 3}

\section{Fundamental Regressions}

In Panel A of Table 3, "Precrisis" reports the SUR regression coefficients for equation 2 estimated over the precrisis subperiod (Dec. 23, 2005-July 30, 2007). The dependent variable is the change in the CDS spread of the EDF-sorted portfolio. "Marginal Crisis Effects" is the difference between crisis coefficients (unreported) and precrisis coefficients reported previously. Crisis coefficients are obtained by reestimating equation 2 over the crisis subperiod (July 31, 2007-Mar. 9, 2009). I use a simple Wald test of the cross-equation restriction to evaluate the equality of coefficients across subperiods. $p$-values for the Wald test are reported in square brackets, and Z-statistics for the SUR coefficients are reported in parentheses. Panel $\mathrm{B}$ reports the percentage of the increase in covariance explained by the model $\left(\Delta \widehat{\operatorname{Cov}}(i, j)_{\text {model }} / \Delta \widehat{\operatorname{Cov}}(i, j)_{\text {sample }}\right)$, where $\widehat{\operatorname{cov}}(i, j)_{\tau, \text { model }}=\hat{\beta}_{\tau, i} \hat{\Sigma}_{\tau} \hat{\beta}_{\tau, j}^{\prime}$, and $\Delta$ represents the difference between crisis and precrisis covariance. I use a simple nonparametric bootstrap with replacement (1,000 repetitions) and percentile confidence intervals to determine whether the ratio is significantly different from $0 .{ }^{*},{ }^{\star *}$, and ${ }^{* \star *}$ indicate statistical significance at the $10 \%, 5 \%$, and $1 \%$ levels, respectively.

Panel A. Fundamental Regressions

\begin{tabular}{|c|c|c|c|c|c|}
\hline & 1 (Low EDF) & 2 & 3 & 4 & 5 (High EDF) \\
\hline \multicolumn{6}{|l|}{ Precrisis } \\
\hline SP500 & $\begin{array}{l}-0.0013^{\star \star \star} \\
(-5.72)\end{array}$ & $\begin{array}{l}-0.0023^{\star \star \star} \\
(-7.04)\end{array}$ & 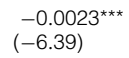 & $\begin{array}{l}-0.0033^{\star \star \star} \\
(-7.06)\end{array}$ & $\begin{array}{l}-0.0054^{\star \star *} \\
(-7.71)\end{array}$ \\
\hline$\triangle$ SPVOI & $\begin{array}{l}0.0048 \\
(1.27)\end{array}$ & $\begin{array}{l}-0.0050 \\
(-1.07)\end{array}$ & $\begin{array}{l}0.0040 \\
(0.73)\end{array}$ & $\begin{array}{l}0.0002 \\
(0.03)\end{array}$ & $\begin{array}{l}-0.0107 \\
(-1.42)\end{array}$ \\
\hline$\Delta \mathrm{RF} 3 \mathrm{M}$ & $\begin{array}{l}-0.0085 \\
(-1.48)\end{array}$ & $\begin{array}{l}-0.0187^{* *} \\
(-2.27)\end{array}$ & $\begin{array}{l}-0.0105 \\
(-1.15)\end{array}$ & $\begin{array}{l}-0.0268^{\star \star \star} \\
(-2.35)\end{array}$ & $\begin{array}{l}-0.0426^{* * *} \\
(-2.60)\end{array}$ \\
\hline$\triangle$ SLOPE & $\begin{array}{l}-0.0043 \\
(-1.27)\end{array}$ & $\begin{array}{l}-0.0115^{\star \star \star} \\
(-2.34)\end{array}$ & $\begin{array}{l}-0.0114^{\star \star} \\
(-2.10)\end{array}$ & $\begin{array}{l}-0.0201^{\star \star *} \\
(-2.96)\end{array}$ & $\begin{array}{l}-0.0381^{\text {}} \\
(-3.91)\end{array}$ \\
\hline $\mathrm{HB}$ & $\begin{array}{l}0.0000 \\
(0.07)\end{array}$ & $\begin{array}{l}0.0000 \\
(-0.08)\end{array}$ & $\begin{array}{l}-0.0001 \\
(-0.81)\end{array}$ & $\begin{array}{l}0.0000 \\
(-0.24)\end{array}$ & $\begin{array}{l}-0.0005 \\
(-1.60)\end{array}$ \\
\hline$\Delta \mathrm{DEF}$ & $\begin{array}{l}0.0557^{\star \star \star} \\
(5.31)\end{array}$ & $\begin{array}{l}0.0858^{\star * *} \\
(5.72)\end{array}$ & 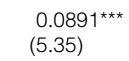 & $\begin{array}{l}0.1522^{\star \star \star} \\
(7.30)\end{array}$ & 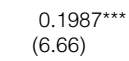 \\
\hline SMB & $\begin{array}{l}-0.0001 \\
(-0.31)\end{array}$ & $\begin{array}{l}0.0000 \\
(0.07)\end{array}$ & $\begin{array}{l}-0.0002 \\
(-0.33)\end{array}$ & $\begin{array}{l}0.0002 \\
(0.27)\end{array}$ & $\begin{array}{l}0.0004 \\
(0.39)\end{array}$ \\
\hline HML & $\begin{array}{l}-0.0020^{\star \star \star} \\
(-3.20)\end{array}$ & $\begin{array}{l}-0.0028^{\star * *} \\
(-3.11)\end{array}$ & $\begin{array}{l}-0.0031^{\star \star \star} \\
(-3.03)\end{array}$ & $\begin{array}{l}-0.0044^{\star \star *} \\
(-3.47)\end{array}$ & $\begin{array}{l}-0.0060^{* * *} \\
(-3.31)\end{array}$ \\
\hline PORTRET & $\begin{array}{l}-0.0001 \\
(-0.26)\end{array}$ & $\begin{array}{l}-0.0002 \\
(-0.54)\end{array}$ & $\begin{array}{l}-0.0003 \\
(-0.96)\end{array}$ & $\begin{array}{l}-0.0007^{\text {** }} \\
(-2.09)\end{array}$ & $\begin{array}{l}-0.0001 \\
(-0.21)\end{array}$ \\
\hline$\triangle P O R T V O L$ & $\begin{array}{l}-0.0017 \\
(-0.55)\end{array}$ & $\begin{array}{l}0.0014 \\
(0.45)\end{array}$ & $\begin{array}{l}-0.0020 \\
(-0.55)\end{array}$ & $\begin{array}{l}-0.0041 \\
(-1.23)\end{array}$ & $\begin{array}{l}0.0005 \\
(0.34)\end{array}$ \\
\hline \multicolumn{6}{|c|}{ Marginal Crisis Effects } \\
\hline SP500 & $\begin{array}{l}-0.0016^{\star \star \star} \\
{[0.01]}\end{array}$ & $\begin{array}{l}-0.0028^{* * *} \\
{[0.00]}\end{array}$ & $\begin{array}{l}-0.0041^{\star \star \star} \\
{[0.00]}\end{array}$ & $\begin{array}{l}-0.0064^{* * *} \\
{[0.00]}\end{array}$ & $\begin{array}{l}-0.0101^{* \star *} \\
{[0.00]}\end{array}$ \\
\hline$\triangle$ SPVOI & $\begin{array}{c}-0.0013 \\
{[0.89]}\end{array}$ & $\begin{array}{l}0.0078 \\
{[0.55]}\end{array}$ & $\begin{array}{c}0.014 \\
{[0.38]}\end{array}$ & $\begin{array}{r}0.001 \\
{[0.96]}\end{array}$ & $\begin{array}{c}0.0191 \\
{[0.55]}\end{array}$ \\
\hline$\Delta \mathrm{RF} 3 \mathrm{M}$ & $\begin{array}{c}-0.0362^{\star \star \star} \\
{[0.00]}\end{array}$ & $\begin{array}{c}-0.025 \\
{[0.17]}\end{array}$ & $\begin{array}{c}-0.0564^{\star \star} \\
{[0.02]}\end{array}$ & $\begin{array}{c}-0.0702^{\star \star} \\
{[0.03]}\end{array}$ & $\begin{array}{l}-0.1421^{\star \star *} \\
{[0.01]}\end{array}$ \\
\hline$\triangle$ SLOPE & $\begin{array}{l}-0.0248^{\star \star} \\
{[0.03]}\end{array}$ & $\begin{array}{c}-0.0121 \\
{[0.48]}\end{array}$ & $\begin{array}{c}-0.0266 \\
{[0.24]}\end{array}$ & $\begin{array}{c}-0.0449 \\
{[0.15]}\end{array}$ & $\begin{array}{c}-0.103^{\star \star} \\
{[0.05]}\end{array}$ \\
\hline $\mathrm{HB}$ & $\begin{array}{l}-0.0011^{\star * *} \\
{[0.00]}\end{array}$ & $\begin{array}{l}-0.0013^{* *} \\
{[0.02]}\end{array}$ & $\begin{array}{c}-0.0016^{\star \star} \\
{[0.03]}\end{array}$ & $\begin{array}{c}-0.0022^{\star \star} \\
{[0.03]}\end{array}$ & $\begin{array}{l}-0.0039^{* *} \\
{[0.03]}\end{array}$ \\
\hline$\triangle \mathrm{DEF}$ & $\begin{array}{c}-0.0075 \\
{[0.79]}\end{array}$ & $\begin{array}{c}-0.0066 \\
{[0.87]}\end{array}$ & $\begin{array}{l}0.0386 \\
{[0.48]}\end{array}$ & $\begin{array}{c}-0.0206 \\
{[0.79]}\end{array}$ & $\begin{array}{c}0.0496 \\
{[0.69]}\end{array}$ \\
\hline SMB & $\begin{array}{l}0.0018 \\
{[0.19]}\end{array}$ & $\begin{array}{l}0.0016 \\
{[0.40]}\end{array}$ & $\begin{array}{l}0.0007 \\
{[0.79]}\end{array}$ & $\begin{array}{l}0.0004 \\
{[0.91]}\end{array}$ & $\begin{array}{l}0.0082 \\
{[0.18]}\end{array}$ \\
\hline HML & $\begin{array}{l}0.0035^{\star \star \star} \\
{[0.01]}\end{array}$ & $\begin{array}{l}0.005^{\star \star \star} \\
{[0.01]}\end{array}$ & $\begin{array}{l}0.0047^{*} \\
{[0.06]}\end{array}$ & $\begin{array}{l}0.0043 \\
{[0.21]}\end{array}$ & $\begin{array}{c}0.01^{*} \\
{[0.09]}\end{array}$ \\
\hline PORTRET & $\begin{array}{l}0.0014^{\star} \\
{[0.09]}\end{array}$ & $\begin{array}{c}-0.001 \\
{[0.35]}\end{array}$ & $\begin{array}{c}-0.0006 \\
{[0.53]}\end{array}$ & $\begin{array}{l}0.0005 \\
{[0.62]}\end{array}$ & $\begin{array}{l}-0.005^{\star \star \star} \\
{[0.00]}\end{array}$ \\
\hline$\triangle \mathrm{PORTVOL}$ & $\begin{array}{c}0.009 \\
{[0.27]}\end{array}$ & $\begin{array}{c}-0.0077 \\
{[0.40]}\end{array}$ & $\begin{array}{l}-0.017^{\star *} \\
{[0.03]}\end{array}$ & $\begin{array}{l}0.0111 \\
{[0.25]}\end{array}$ & $\begin{array}{c}-0.0008 \\
{[0.85]}\end{array}$ \\
\hline $\begin{array}{l}R^{2} \text { Pre } \\
R^{2} \text { Post }\end{array}$ & $\begin{array}{l}0.1994 \\
0.2198\end{array}$ & $\begin{array}{l}0.2518 \\
0.2210\end{array}$ & $\begin{array}{l}0.2220 \\
0.2198\end{array}$ & $\begin{array}{l}0.2942 \\
0.2424\end{array}$ & $\begin{array}{l}0.3303 \\
0.2689\end{array}$ \\
\hline
\end{tabular}

default is negligible; thus, VaR should be interpreted as an upper bound. In the case of default, notional payments will offset. 
TABLE 3 (continued)

Fundamental Regressions

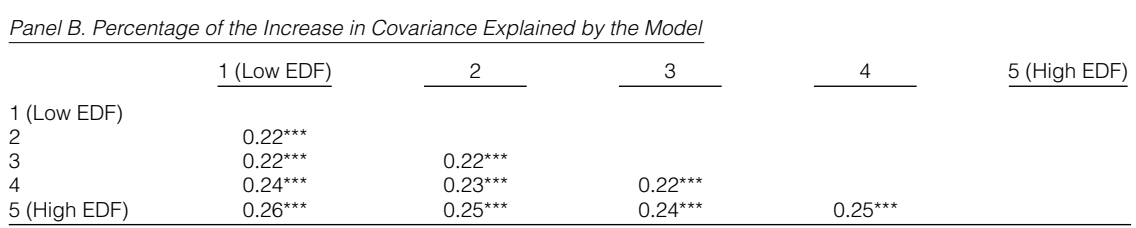

covariance is economically meaningful. In the crisis, average sample VaR rose from 4,205 to $\$ 47,499$ per $\$ 10 \mathrm{M}$ of notional value, constituting a $770 \%$ increase over the counterfactual VaR of $\$ 5,450$.

However, only a fraction of the increase in VaR relates to fundamentals. Using fitted values, I find that average model-implied VaR increased by $\$ 23,178$ in the crisis, which accounts for approximately half of the $\$ 43,293$ increase in average sample VaR. Nevertheless, this is substantially larger than the $\$ 1,052$ increase in average counterfactual VaR. ${ }^{12}$

\section{Liquidity}

In general, protection sellers are compensated for liquidity risk, resulting in wider spreads, when protection buyers are wealthier and more risk averse (see Bongaerts et al. (2011)). A priori, one would expect wealthier and more riskaverse investors to purchase protection, especially in times of crisis, which suggests a positive association between illiquidity and CDS spread changes. This subsection investigates how the link between CDS spreads and liquidity, in the form of transaction costs, bond liquidity, systematic liquidity, and funding liquidity, affects the increase in covariance observed in the crisis.

Transaction costs in the CDS market compensate dealers for exposure to asymmetric information risk and inventory cost (see Tang and Yan (2008)). Inventory costs arise from margins, collateral requirements, payments on open positions, and the cost of offsetting contracts. Margin surveys from the International Swaps and Derivatives Association (ISDA) show that margins and collateral requirements grew throughout the crisis. Moreover, rising CDS spreads made it more costly to offset protection sold, on average, relative to the precrisis period. Therefore, transaction costs provide a plausible link between CDS spread changes that may have facilitated the increase in covariance.

Following Bongaerts et al. (2011), I measure transaction costs as the equalweighted average bid-ask spread over all contracts in a portfolio (PORTBA) or over all contracts in the sample (BIDASK).

\footnotetext{
${ }^{12}$ Combine portfolios hold approximately $\$ 60 \mathrm{M}$ of notional value each. Rescaling the $\$ 47,499$ reported earlier yields an average portfolio VaR of $\$ 2.9 \mathrm{M}$ in the crisis. Although it was potentially modest in level, the unexpected increase in VaR and associated capital requirements likely further stressed banks' balance sheets in the midst of capital shortfalls. Moreover, even small changes in the perceived predictability of asset returns can have large ramifications for asset allocation (see Kandel and Stambaugh (1996)).
} 
In addition, CDS and bond liquidity are likely linked through the trading of credit risk. For example, Acharya et al. (2015) show that CDS dealers restricted their market-making services in response to bond order imbalances around the 2005 downgrade of Ford and GM. Further, Pu (2009) documents commonality between CDS and bond liquidity proxies. Therefore, I construct the average Amihud (AMIHUD), principal traded (VOLUME), and number of trades (NTRADE) each day, from TRACE, to capture aggregate price impact and trading intensity in the bond market, respectively. Additional details about these and all other variables are provided in the Appendix.

Next, CDS market participants may require compensation for exposure to systematic liquidity risk (see Pástor and Stambaugh (2003), Chen, Lesmond, and Wei (2007)). As a result, one would expect covariance to increase in states of heightened liquidity risk. I employ the on-the-run Treasury spread (ONOFF), the repurchase (repo) spread (ONREPO), and the liquidity component of the TED spread (OISTB) to capture systematic liquidity (see Eichengreen, Mody, Nedeljkovic, and Sarno (2012), Fleming (2003), and Liu, Longstaff, and Mandell (2006)).

Finally, liquidity may have suffered from the loss of investors' ability to fund their trading activity (see Brunnermeier and Pedersen (2009)). Although CDS contracts are unfunded, counterparties usually post the initial amount at inception; additional collateral payments, which are contingent on the credit quality of both the reference entity and counterparty, are required for the duration of open positions. These collateral requirements can represent a significant cost to market participants. In 2009, the ISDA reported that hedge funds posted collateral equal to $140 \%$ of their net derivatives exposure, on average. ${ }^{13}$

To measure funding liquidity, I construct i) the volume ratio of high- to lowvolatility stocks (VRATIO) in the CRSP data, which may contain useful information about hedge fund deleveraging activity (see Ben-David, Franzoni, and Moussawi (2012)); ii) the betting-against-beta strategy (BAB) return proposed by Frazzini and Pedersen (2013); and iii) dealer leverage-mimicking portfolio returns (LMP), a measure that Adrian, Etula, and Muir (2013) argue captures dealer funding constraints.

Results reported in Panel A of Table 4 show that changes in transaction costs were clearly the main source of liquidity risk for investment-grade CDS contracts prior to the crisis. The positive sign is consistent with prior work and suggests that protection buyers were wealthier and more risk averse than sellers. Funding liquidity also played an important role, especially with respect to dealer leverage, which was positive and significantly related to CDS spread changes for 4 out of the 5 portfolios.

Next, I turn to the change in beta; a number of these results reported in the lower half of Panel A of Table 4 provide insight into the increase in covariance. First, the change in exposures to systematic liquidity was insignificant across most proxies in the crisis. Therefore, it did not affect the increase in covariance. Although exposures to $\triangle$ OISTB increased significantly in absolute value, the

\footnotetext{
${ }^{13}$ It is important to note that funding liquidity likely had a larger effect on bond prices than CDS spreads because they are funded assets (see Mitchell and Pulvino (2012)).
} 
coefficient itself became negative. This negative relationship is inconsistent with a liquidity risk interpretation. ${ }^{14}$ Ultimately, the impact of the change in sign on covariance will depend on the change in $\Sigma_{\tau}$.

Second, the change in exposures to $\triangle \mathrm{VOL}$ suggests that bond trading intensity had a stronger impact on CDS spread changes in the crisis. This may suggest that hedging demand increased as bonds became more difficult to trade, which is supported by the decrease in average trading volume (VOL) over this period.

Third, funding liquidity played a significantly more important role in determining CDS spread changes during the crisis. Clearly, the increase in exposures to BAB and LMP across all portfolios supports this view. The change in LMP shows that a $1 \%$ increase in dealer leverage is associated with a $0.30 \mathrm{bps}$ increase in daily CDS spreads prior to the crisis compared to 1.68 bps during the crisis. Similarly, the negative change in $\mathrm{BAB}$ exposures implies that CDS spreads increased due to speculators' impaired access to funding. ${ }^{15}$ Moreover, the precrisis analysis shows that BAB was insignificant when funding was readily available, which supports its interpretation as a measure of funding constraints.

Finally, precrisis (crisis) $R^{2}$ increased from approximately $26 \%(23 \%)$ to $31 \%(34 \%)$ after controlling for liquidity.

Next, I explore the joint effect of the change in betas and $\Sigma_{\tau}$ by evaluating the percentage of the increase in covariance captured by the model (COVR). These results are reported below the diagonal in Panel B of Table 4. They show that controlling for the change in both exposures and the variance-covariance of fundamentals and liquidity captures, on average, $33.4 \%$ of the increase in sample covariance.

To isolate the impact of liquidity, I compute the marginal increase in COVR by subtracting the matrix in Panel B of Table 4 below the diagonal from that reported in Panel B of Table 3. These results are reported above the diagonal and show that liquidity accounts for $10 \%$ of the total increase in covariance, on average, across portfolio pairs. This number decreases to approximately $5 \%$ (unreported) when $\Sigma_{\tau}$ is held constant over the full sample period.

Finally, I investigate the economic magnitude. These findings show that controlling for liquidity increased the average model-implied VaR from $\$ 25,926$ to $\$ 30,430$ in the crisis per $\$ 10 \mathrm{M}$ of notional value. This is notably higher than the $\$ 4,016$ counterfactual VaR obtained by holding the covariance structure constant at its average precrisis level. However, it still falls short of explaining the full increase in sample VaR.

In conclusion, increased exposure to bond and funding liquidity along with changes in $\Sigma_{\tau}$ played both an economically and statistically significant role in

\footnotetext{
${ }^{14}$ OISTB increases with illiquidity; however, it decreased in the crisis, which may have resulted from government liquidity infusions into the banking sector. This likely decreased the federal funds and overnight indexed swap (OIS) rate relative to RF3M. Therefore, the negative coefficient implies a marginal increase in average portfolio CDS spreads during the crisis, which may reflect a negative market reaction to government intervention.

${ }^{15}$ The spread between high- and low-beta asset returns widens as funding liquidity becomes impaired. However, it is inverted after rescaling returns to obtain unit beta. Therefore, constrained funding liquidity is captured by larger negative BAB.
} 


\section{TABLE 4}

\section{Liquidity Regressions}

In Panel A of Table 4, "Precrisis" reports SUR regression coefficients for liquidity variables over the precrisis subperiod (Dec. 23, 2005-July 30, 2007). The dependent variable is the change in the CDS spread of the EDF-sorted portfolio. Fundamental variables are included but not reported. All variables are in basis points. "Marginal Crisis Effects" shows the change in regression coefficients over the crisis subperiod (July 31, 2007-Mar. 9, 2009) obtained by reestimating the SUR regressions over the crisis subperiod and subtracting crisis and precrisis coefficients. The $p$-value for the Wald test of each cross-equation restriction is reported in square brackets. $Z$-statistics for SUR coefficients are reported in parentheses. Panel B reports the percentage of the increase in covariance explained by the model $\left(\Delta \widehat{\operatorname{cov}}(i, j)_{\text {model }} / \Delta \widehat{\operatorname{cov}}(i, j)_{\text {sample }}\right)$, where $\widehat{\operatorname{cov}}(i, j)_{\tau, \text { model }}=\hat{\beta}_{\tau, j} \hat{\Sigma}_{\tau} \hat{\beta}_{\tau, j}^{\prime}$, and $\Delta$ represents the difference between crisis and precrisis covariance below the diagonal. Above the diagonal, I report the marginal contribution from liquidity. I use a simple nonparametric bootstrap with replacement and percentile confidence intervals (1,000 repetitions) to determine whether the ratio is significantly different from $0 .{ }^{*},{ }^{* \star}$, and ${ }^{* \star}$ indicate statistical significance at the $10 \%, 5 \%$, and $1 \%$ levels, respectively.

Panel A. Liquidity Regressions

\begin{tabular}{|c|c|c|c|c|c|}
\hline & 1 (Low EDF) & 2 & 3 & 4 & 5 (High EDF) \\
\hline \multicolumn{6}{|l|}{ Precrisis } \\
\hline$\triangle$ OISTB & $\begin{array}{l}0.0036 \\
(0.27)\end{array}$ & $\begin{array}{l}0.0116 \\
(0.59)\end{array}$ & $\begin{array}{l}-0.0045 \\
(-0.21)\end{array}$ & $\begin{array}{l}-0.0045 \\
(-0.17)\end{array}$ & $\begin{array}{l}0.0021 \\
(0.05)\end{array}$ \\
\hline$\triangle O N O F F$ & $\begin{array}{l}0.0303 \\
(0.75)\end{array}$ & $\begin{array}{l}0.0309 \\
(0.52)\end{array}$ & $\begin{array}{l}-0.0081 \\
(-0.13)\end{array}$ & $\begin{array}{l}-0.0188 \\
(-0.24)\end{array}$ & $\begin{array}{l}0.0031 \\
(0.03)\end{array}$ \\
\hline$\triangle O N R E P O$ & $\begin{array}{l}0.0029 \\
(0.34)\end{array}$ & $\begin{array}{l}0.0055 \\
(0.43)\end{array}$ & $\begin{array}{l}0.0022 \\
(0.16)\end{array}$ & $\begin{array}{l}0.0119 \\
(0.70)\end{array}$ & $\begin{array}{l}0.0190 \\
(0.75)\end{array}$ \\
\hline$\triangle \mathrm{AMIHUD}$ & $\begin{array}{l}0.0294 \\
(0.47)\end{array}$ & $\begin{array}{l}0.0210 \\
(0.23)\end{array}$ & $\begin{array}{l}0.0229 \\
(0.23)\end{array}$ & $\begin{array}{l}0.0309 \\
(0.25)\end{array}$ & $\begin{array}{l}0.0629 \\
(0.34)\end{array}$ \\
\hline$\Delta \mathrm{VOL}$ & $\begin{array}{l}-0.0158 \\
(-0.70)\end{array}$ & $\begin{array}{l}-0.0324 \\
(-0.98)\end{array}$ & $\begin{array}{l}-0.0148 \\
(-0.41)\end{array}$ & $\begin{array}{l}-0.0270 \\
(-0.61)\end{array}$ & $\begin{array}{l}-0.0076 \\
(-0.11)\end{array}$ \\
\hline$\triangle \mathrm{NTRADE}$ & $\begin{array}{l}-0.0183 \\
(-0.68)\end{array}$ & $\begin{array}{l}-0.0196 \\
(-0.49)\end{array}$ & $\begin{array}{l}-0.0614 \\
(-1.43)\end{array}$ & $\begin{array}{l}-0.0619 \\
(-1.16)\end{array}$ & $\begin{array}{l}-0.0612 \\
(-0.77)\end{array}$ \\
\hline$\triangle$ BIDASK & $\begin{array}{l}14.3027^{\star \star \star} \\
(2.58)\end{array}$ & $\begin{array}{l}22.6313^{\star \star \star} \\
(2.78)\end{array}$ & $\begin{array}{l}21.0862^{\star \star \star \star} \\
(2.38)\end{array}$ & $\begin{array}{l}50.5143^{\star \star \star \star} \\
(2.60)\end{array}$ & $\begin{array}{l}41.0853^{\star *} \\
(2.23)\end{array}$ \\
\hline$\triangle$ VRATIO & $\begin{array}{l}-0.0102 \\
(-1.04)\end{array}$ & $\begin{array}{l}-0.0326^{* *} \\
(-2.27)\end{array}$ & $\begin{array}{l}-0.0286^{\star} \\
(-1.84)\end{array}$ & $\begin{array}{l}-0.0306 \\
(-1.59)\end{array}$ & $\begin{array}{l}-0.0567^{\star *} \\
(-1.97)\end{array}$ \\
\hline BAB & $\begin{array}{l}-0.0001 \\
(-0.41)\end{array}$ & $\begin{array}{l}-0.0004 \\
(-0.87)\end{array}$ & $\begin{array}{l}-0.0006 \\
(-1.11)\end{array}$ & $\begin{array}{l}-0.0010 \\
(-1.62)\end{array}$ & $\begin{array}{l}-0.0014 \\
(-1.53)\end{array}$ \\
\hline LMP & $\begin{array}{l}0.0012^{\star \star \star} \\
(2.33)\end{array}$ & $\begin{array}{l}0.0021^{\star \star \star *} \\
(2.72)\end{array}$ & $\begin{array}{l}0.0010 \\
(1.16)\end{array}$ & $\begin{array}{l}0.0030^{\star \star \star} \\
(2.92)\end{array}$ & $\begin{array}{l}0.0041^{\star \star \star} \\
(2.68)\end{array}$ \\
\hline$\triangle$ PORTBA & $\begin{array}{l}4.8927 \\
(1.63)\end{array}$ & $\begin{array}{l}-3.6983 \\
(-0.92)\end{array}$ & $\begin{array}{l}1.5864 \\
(0.45)\end{array}$ & $\begin{array}{l}2.3265 \\
(0.48)\end{array}$ & $\begin{array}{l}-9.6089 \\
(-1.35)\end{array}$ \\
\hline \multicolumn{6}{|c|}{ Marginal Crisis Effects } \\
\hline$\Delta$ OISTB & $\begin{array}{c}-0.0462^{\star} \\
{[0.06]}\end{array}$ & $\begin{array}{l}-0.0776^{\star *} \\
{[0.02]}\end{array}$ & $\begin{array}{c}-0.0836^{\star} \\
{[0.07]}\end{array}$ & $\begin{array}{c}-0.0963 \\
{[0.12]}\end{array}$ & $\begin{array}{r}-0.077 \\
{[0.46]}\end{array}$ \\
\hline$\triangle \mathrm{ONOFF}$ & $\begin{array}{r}0.017 \\
{[0.86]}\end{array}$ & $\begin{array}{c}-0.046 \\
{[0.73]}\end{array}$ & $\begin{array}{c}-0.0139 \\
{[0.94]}\end{array}$ & $\begin{array}{l}0.0009 \\
{[1.00]}\end{array}$ & $\begin{array}{c}-0.0424 \\
{[0.92]}\end{array}$ \\
\hline$\triangle$ ONREPO & $\begin{array}{c}-0.0067 \\
{[0.54]}\end{array}$ & $\begin{array}{c}-0.0086 \\
{[0.58]}\end{array}$ & $\begin{array}{c}-0.0016 \\
{[0.93]}\end{array}$ & $\begin{array}{c}-0.0205 \\
{[0.41]}\end{array}$ & $\begin{array}{c}-0.0403 \\
{[0.31]}\end{array}$ \\
\hline$\triangle \mathrm{AMIHUD}$ & $\begin{array}{c}-0.076 \\
{[0.81]}\end{array}$ & $\begin{array}{c}-0.4414 \\
{[0.32]}\end{array}$ & $\begin{array}{c}-0.4173 \\
{[0.51]}\end{array}$ & $\begin{array}{c}-0.7137 \\
{[0.41]}\end{array}$ & $\begin{array}{c}-0.7289 \\
{[0.63]}\end{array}$ \\
\hline$\Delta \mathrm{VOL}$ & $\begin{array}{c}-0.3044^{* *} \\
{[0.03]}\end{array}$ & $\begin{array}{l}-0.4514^{\star \star} \\
{[0.02]}\end{array}$ & $\begin{array}{c}-0.5376^{\star} \\
{[0.06]}\end{array}$ & $\begin{array}{c}-0.6347 \\
{[0.10]}\end{array}$ & $\begin{array}{c}-1.1286^{*} \\
{[0.09]}\end{array}$ \\
\hline$\triangle \mathrm{NTRADE}$ & $\begin{array}{c}-0.048 \\
{[0.62]}\end{array}$ & $\begin{array}{c}-0.0642 \\
{[0.64]}\end{array}$ & $\begin{array}{c}-0.0568 \\
{[0.77]}\end{array}$ & $\begin{array}{c}-0.3326 \\
{[0.21]}\end{array}$ & $\begin{array}{c}-0.1265 \\
{[0.78]}\end{array}$ \\
\hline$\triangle \mathrm{BIDASK}$ & $\begin{array}{l}17.3756 \\
{[0.14]}\end{array}$ & $\begin{array}{l}19.4478 \\
{[0.24]}\end{array}$ & $\begin{array}{l}2.9993 \\
{[0.90]}\end{array}$ & $\begin{array}{l}42.6496 \\
{[0.22]}\end{array}$ & $\begin{array}{c}112.8882^{\star *} \\
{[0.03]}\end{array}$ \\
\hline$\triangle$ VRATIO & $\begin{array}{l}0.0157 \\
{[0.25]}\end{array}$ & $\begin{array}{l}0.033^{*} \\
{[0.09]}\end{array}$ & $\begin{array}{l}0.0358 \\
{[0.16]}\end{array}$ & $\begin{array}{r}0.036 \\
{[0.28]}\end{array}$ & $\begin{array}{l}0.1068^{\star *} \\
{[0.05]}\end{array}$ \\
\hline BAB & $\begin{array}{l}-0.0014^{\star \star} \\
{[0.01]}\end{array}$ & $\begin{array}{l}-0.0017^{* *} \\
{[0.03]}\end{array}$ & $\begin{array}{l}-0.0029^{\star \star \star} \\
{[0.01]}\end{array}$ & $\begin{array}{c}-0.0023^{*} \\
{[0.10]}\end{array}$ & $\begin{array}{c}-0.0042^{*} \\
{[0.07]}\end{array}$ \\
\hline LMP & $\begin{array}{l}0.0049^{\star \star \star} \\
{[0.00]}\end{array}$ & $\begin{array}{l}0.0077^{\star * \star} \\
{[0.00]}\end{array}$ & $\begin{array}{l}0.0128^{\star \star \star} \\
{[0.00]}\end{array}$ & $\begin{array}{l}0.0138^{\star \star \star \star} \\
{[0.00]}\end{array}$ & $\begin{array}{l}0.0246^{\star \star *} \\
{[0.00]}\end{array}$ \\
\hline$\triangle \mathrm{PORTBA}$ & $\begin{array}{c}4.7391 \\
{[0.74]}\end{array}$ & $\begin{array}{l}24.1028^{\star *} \\
{[0.01]}\end{array}$ & $\begin{array}{c}-1.2264 \\
{[0.76]}\end{array}$ & $\begin{array}{c}-2.2623 \\
{[0.64]}\end{array}$ & $\begin{array}{l}13.7088 \\
{[0.12]}\end{array}$ \\
\hline $\begin{array}{l}R^{2} \text { Pre } \\
R^{2} \text { Post }\end{array}$ & $\begin{array}{l}0.2622 \\
0.3301\end{array}$ & $\begin{array}{l}0.3060 \\
0.3641\end{array}$ & $\begin{array}{l}0.2755 \\
0.3163\end{array}$ & $\begin{array}{l}0.3751 \\
0.3480\end{array}$ & $\begin{array}{l}0.3799 \\
0.3517\end{array}$ \\
\hline$R^{2}$ Post & 0.3301 & 0.3641 & 0.3163 & 0.3480 & $\begin{array}{c}0.3517 \\
\text { (on next page) }\end{array}$ \\
\hline
\end{tabular}


TABLE 4 (continued)

Liquidity Regressions

Panel B. Percentage of the Increase in Covariance Explained by the Model

\begin{tabular}{|c|c|c|c|c|c|}
\hline & 1 (Low EDF) & 2 & 3 & 4 & 5 (High EDF) \\
\hline 1 (Low EDF) & & $0.11^{\star \star \star}$ & $0.09^{\star \star \star \star}$ & $0.10^{\star \star \star \star}$ & $0.10^{\star \star \star}$ \\
\hline 2 & $0.33^{* * * *}$ & & $0.10^{* \star *}$ & $0.11^{\star * \star *}$ & $0.11^{* * * k}$ \\
\hline 3 & $0.31^{\star * \star *}$ & $0.32^{\star \star \star}$ & & $0.09^{* * *}$ & $0.09^{* * * * k}$ \\
\hline 4 & $0.34^{* * *}$ & $0.34^{\star \star \star *}$ & $0.31^{\star \star \star}$ & & $0.09^{\star * * k}$ \\
\hline 5 (High EDF) & $0.36^{\star * * *}$ & $0.36^{\star \star *}$ & $0.33^{\star \star * *}$ & $0.34^{* * *}$ & \\
\hline
\end{tabular}

increasing covariance during the crisis. Moreover, the joint effect appears to be evenly distributed between changes in exposures and factor variance-covariance.

\section{Counterparty Risk}

The risk that counterparties fail to deliver on their contractual obligations may have increased covariance for at least three reasons. First, a joint deterioration in the credit quality of protection sellers may have reduced the value of their insurance guarantees (see Arora et al. (2012)). In this case, CDS spread changes would likely have become more negatively associated with bank-sector credit risk, thereby increasing commonality.

Second, increased counterparty risk could have induced "gridlock." In gridlock, dealers' reluctance to trade with each other leads to higher CDS spreads that compensate for expected losses from dealer defaults (see Brunnermeier (2009)). This mechanism implies a stronger positive link between CDS spread changes and bank-sector credit risk, which would have increased covariance.

Finally, an increase in the cross-sectional variation of dealers' credit quality may have caused demand for credit protection to shift toward a smaller group of high-quality dealers. This is because investors may have sought to purchase contracts from high-quality dealers in an effort to minimize expected losses. As a result, covariance would likely have increased to reflect the higher concentration in market-making services.

To test the first two mechanisms, I construct the overnight index swap spread (OIS), the 3-month asset-backed commercial paper spread (ABCP), and a valueweighted index of dealer equity returns (16 licensed dealers for the CDX index) to proxy for bank-sector credit risk (see Eichengreen et al. (2012)). A positive relationship between CDS spread changes and bank-sector credit risk supports the first mechanism, and a negative relationship supports the second. For the last mechanism, I use the log difference between the maximum and median daily stock return of the 16 licensed CDX dealers (CPDIF) to capture dealer risk dispersion. A positive change in the coefficient is consistent with an increase in concentration.

Estimated regression coefficients for counterparty risk variables, which are added to the fundamental model, are reported in Panel A of Table 5. They show that counterparty risk was not a significant determinant of CDS spread changes prior to the crisis. Moreover, the change in exposures is insignificant across most 
proxies and portfolios. These results suggest that the increase in sample covariance was not driven by increased exposure to counterparty risk. ${ }^{16}$

Next, I consider the percentage increase in covariance captured by the model and the marginal contribution from counterparty risk variables. These results are reported in Panel B of Table 5. Consistent with Arora et al. (2012), I find no evidence that counterparty risk contributed to the observed increase in covariance.

As a result, it had little impact on VaR. Controlling for counterparty risk increased model-implied VaR from $\$ 25,926$ to $\$ 26,614$ in the crisis, which is drastically below the sample VaR observed in the data.

\title{
TABLE 5
}

\section{Counterparty Risk Regressions}

\begin{abstract}
In Panel A of Table 5, "Precrisis" reports SUR regression coefficients for counterparty risk variables over the precrisis subperiod (Dec. 23, 2005-July 30, 2007). The dependent variable is the change in the CDS spread of the EDF-sorted portfolio. Fundamental variables are included but not reported. All variables are in basis points. "Marginal Crisis Effects" shows the change in regression coefficients over the crisis subperiod (July 31, 2007-Mar. 9, 2009) obtained by reestimating the SUR regressions over the crisis subperiod and subtracting crisis and precrisis coefficients. The $p$-value for the Wald test of each cross-equation restriction is reported in square brackets. Z-statistics for SUR coefficients are reported in parentheses. Panel B reports the percentage of the increase in covariance explained by the model $\left(\Delta \widehat{\operatorname{cov}}(i, j)_{\text {model }} / \Delta \widehat{\operatorname{cov}}(i, j)_{\text {sample }}\right)$, where $\widehat{\operatorname{cov}}(i, j)_{\tau \text { model }}=\hat{\beta}_{\tau,} \hat{\Sigma}_{\tau} \hat{\beta}_{\tau,}^{\prime}$, and $\Delta$ represents the difference between crisis and precrisis covariance below the diagonal. Above the diagonal, I report marginal contribution from counterparty risk. I use a simple nonparametric bootstrap with replacement and percentile confidence intervals $(1,000$ repetitions) to determine whether the ratio is significantly different from $0 .{ }^{*},{ }^{* *}$, and ${ }^{* * *}$ indicate statistical significance at the $10 \%, 5 \%$, and $1 \%$ levels, respectively.
\end{abstract}

Panel A. Counterparty Risk Regressions

\begin{tabular}{|c|c|c|c|c|c|}
\hline & 1 (Low EDF) & 2 & 3 & 4 & 5 (High EDF) \\
\hline \multicolumn{6}{|l|}{ Precrisis } \\
\hline$\Delta \mathrm{OIS}$ & $\begin{array}{l}-0.0048 \\
(-0.41)\end{array}$ & $\begin{array}{l}-0.0092 \\
(-0.54)\end{array}$ & $\begin{array}{l}0.0050 \\
(0.27)\end{array}$ & $\begin{array}{l}-0.0016 \\
(-0.07)\end{array}$ & $\begin{array}{l}-0.0117 \\
(-0.35)\end{array}$ \\
\hline$\triangle \mathrm{ABCP}$ & $\begin{array}{l}0.0092 \\
(0.55)\end{array}$ & $\begin{array}{l}0.0021 \\
(0.09)\end{array}$ & $\begin{array}{l}-0.0041 \\
(-0.16)\end{array}$ & $\begin{array}{l}-0.0005 \\
(-0.01)\end{array}$ & $\begin{array}{l}0.0133 \\
(0.29)\end{array}$ \\
\hline CPDIF & $\begin{array}{l}-0.0312 \\
(-1.10)\end{array}$ & $\begin{array}{l}-0.0253 \\
(-0.63)\end{array}$ & $\begin{array}{l}-0.0526 \\
(-1.18)\end{array}$ & $\begin{array}{l}0.0201 \\
(0.36)\end{array}$ & $\begin{array}{l}0.0164 \\
(0.21)\end{array}$ \\
\hline VWRET & $\begin{array}{l}-0.0004 \\
(-1.18)\end{array}$ & $\begin{array}{l}-0.0006 \\
(-1.11)\end{array}$ & $\begin{array}{l}-0.0011^{*} \\
(-1.95)\end{array}$ & $\begin{array}{l}-0.0013^{*} \\
(-1.81)\end{array}$ & $\begin{array}{l}-0.0035^{\star \star \star} \\
(-3.59)\end{array}$ \\
\hline \multicolumn{6}{|c|}{ Marginal Crisis Effects } \\
\hline$\Delta \mathrm{OIS}$ & $\begin{array}{l}0.0314^{*} \\
{[0.08]}\end{array}$ & $\begin{array}{l}0.0299 \\
{[0.24]}\end{array}$ & $\begin{array}{l}0.0437 \\
{[0.17]}\end{array}$ & $\begin{array}{l}0.083^{*} \\
{[0.05]}\end{array}$ & $\begin{array}{l}0.115^{\star} \\
{[0.10]}\end{array}$ \\
\hline$\triangle \mathrm{ABCP}$ & $\begin{array}{c}-0.0119 \\
{[0.50]}\end{array}$ & $\begin{array}{c}-0.003 \\
{[0.91]}\end{array}$ & $\begin{array}{l}0.0006 \\
{[0.98]}\end{array}$ & $\begin{array}{c}-0.0129 \\
{[0.73]}\end{array}$ & $\begin{array}{c}-0.0307 \\
{[0.57]}\end{array}$ \\
\hline CPDIF & $\begin{array}{c}-0.2896^{\star \star} \\
{[0.02]}\end{array}$ & $\begin{array}{c}-0.3128^{*} \\
{[0.08]}\end{array}$ & $\begin{array}{c}-0.3872 \\
{[0.12]}\end{array}$ & $\begin{array}{c}-0.5345 \\
{[0.12]}\end{array}$ & $\begin{array}{c}-0.1271 \\
{[0.82]}\end{array}$ \\
\hline VWRET & $\begin{array}{c}-0.0009 \\
{[0.13]}\end{array}$ & $\begin{array}{c}-0.0009 \\
{[0.31]}\end{array}$ & $\begin{array}{r}-0.001 \\
{[0.38]}\end{array}$ & $\begin{array}{c}-0.0014 \\
{[0.37]}\end{array}$ & $\begin{array}{l}0.0002 \\
{[0.94]}\end{array}$ \\
\hline$R^{2}$ Pre & 0.2021 & 0.2589 & 0.2348 & 0.3016 & 0.3565 \\
\hline$R^{2}$ Post & 0.2576 & 0.2403 & 0.2429 & 0.2653 & 0.2757 \\
\hline \multicolumn{6}{|c|}{ Panel B. Ratio of Change in Covariance } \\
\hline & 1 (Low EDF) & 2 & 3 & 4 & $\underline{5 \text { (High EDF) }}$ \\
\hline 1 (Low EDF) & & $0.03^{*}$ & $0.03^{* *}$ & $0.03^{*}$ & 0.01 \\
\hline 2 & $0.25^{\star \star \star}$ & & 0.02 & 0.02 & 0.00 \\
\hline 3 & $0.25^{\star \star \star}$ & $0.24^{* \star \star}$ & & 0.02 & 0.01 \\
\hline 4 & $0.27^{\star \star \star}$ & $0.25^{\star \star \star}$ & $0.25^{\text {** }}$ & & 0.01 \\
\hline 5 (High EDF) & $0.28^{\star \star *}$ & $0.26^{\star \star}$ & $0.25^{\star \star}$ & $0.26^{\star \star}$ & \\
\hline
\end{tabular}

${ }^{16}$ When estimated in conjunction with liquidity proxies, counterparty risk coefficients and their changes are all insignificant. 


\section{Risk Premiums}

By definition, the default risk premium links CDS spreads through investor preference and, therefore, can affect commonality. In general, this premium compensates investors for exposure to three sources of risk: systematic risk, event risk, and recovery risk (see Elton, Gruber, Agrawal, and Mann (2001), Jarrow, Lando, and Yu (2005), Driessen (2005), and Berndt et al. (2008)). Because these risks are likely related, I focus on the broad effect of investor preference rather than identifying the relative importance of each component.

Intuitively, the default risk premium varies with the financial sector's capacity to bear the level of risk in the corporate debt market. Therefore, one would have expected the premium to rise in response to losses in bank capital and increased volatility in bond returns during the crisis. In the absence of external intervention, the higher premium would likely have persisted for several months as new capital flowed into the market (see Duffie (2008), Mitchell, Pedersen, and Pulvino (2007)).

However, government intervention recapitalized financial institutions, likely causing a downward jump in the default risk premium followed by continued downside pressure at each instance (see He and Krishnamurthy (2012)). This ebb and flow of uncertainty and losses against government intervention outlines a plausible mechanism by which changes in the default risk premium may have affected comovement.

It is important to note that the default risk premium differs from the default spread (DEF) used in the fundamental analysis. Gilchrist and Zakrajsek (2012) show that DEF is a poor predictor of real economic activity, especially when compared with the default risk premium, which suggests that the two measures capture different information.

Following Berndt et al. (2008), I estimate the daily default risk premium in the following panel regression using nonfinancial firms: ${ }^{17}$

$$
\ln \left(\mathrm{CDS}_{i}\right)=\alpha+\beta \ln \left(\mathrm{EDF}_{i}\right)+\sum_{j} \gamma_{j} \mathrm{D}_{j}+\mathrm{z}_{i}
$$

where $\ln \left(\mathrm{CDS}_{i}\right)$ and $\ln \left(\mathrm{EDF}_{i}\right)$ represent the natural log of the 5-year CDS spread and 5-year KMV EDF, respectively; $\alpha_{i}$ is the intercept; $\beta$ controls for the nonlinear relationship between the CDS and EDF; $\mathrm{D}_{j}$ is a time fixed effect that equals 1 on day $j$; and $\mathrm{z}_{i}$ is the regression error term.

This yields estimates of $\hat{\gamma}_{j}$ for each day $j$; the inverse log of $\hat{\gamma}_{j}\left(e^{\gamma_{j}}\right)$ is the estimated proportional default risk premium (RP). Intuitively, RP is the average ratio of CDS spread (risk-neutral default probability) to Moody's KMV EDF (physical default probability) on each day over a subset of nonfinancial firms.

Daily EDF data become available on Mar. 1, 2006. Therefore, I eliminate 42 observations from the beginning and end of the sample to maintain a balanced

\footnotetext{
${ }^{17}$ The EDF is a conditional default probability. It is fitted, nonparametrically, from historical default frequencies of firms with the same distance-to-default values; see Crosbie and Bohn (2003), Kealhofer (2003), and Berndt et al. (2008) for additional details. I drop financials to increase the precision of default risk premium estimates. The increased volatility of default probabilities for financials likely made them difficult to predict using historical distance-to-default values.
} 
panel. Unreported analysis confirms that results from Section III, Section IV, and Section V hold on the adjusted sample.

Overall, the model fits the data relatively well; $R^{2}$ is 0.72 , and the intercept is insignificant at the $10 \%$ level. The beta estimate of 0.40 suggests a slightly stronger nonlinearity than the 0.76 reported by Berndt et al. (2008). Importantly, point estimates of the default risk premium range from 0.72 to 3.83 and average 1.64 over the sample period, which is in line with estimates reported by Berndt et al. (2008) and Driessen (2005).

Finally, I project the change in $\triangle \mathrm{RP}$ onto Lehman Brothers bond index returns to avoid regressing CDS spreads on themselves in the regression analysis. This yields the final change in estimated default risk premium $(\Delta \mathrm{RP})$, which is added to the fundamental model to achieve the desired control. ${ }^{18}$

\section{A. Risk Premium Results}

Regression results are reported in Panel A of Table 6. Rows 1 and 3, labeled $\triangle \mathrm{RP}$, show the precrisis level and change in beta, respectively, for each portfolio. These coefficients are closely related to default probabilities (in basis points). Therefore, it is not surprising that coefficients are positive, significant, and monotonically increasing with EDF prior to the crisis.

Interestingly, the change in beta varies drastically across portfolios. Whereas beta for the portfolio with low credit risk increased by only 2 bps, an insignificant change, beta for the portfolio with high credit risk more than doubled. This suggests that investors diversifying across the credit-risk space suffered the largest loss in diversification benefit from exposure to low-credit-quality firms, which is further illustrated by the analysis of COVR.

The results below the diagonal in Panel B of Table 6 show that, on average, $40 \%$ of the increase in covariance can be attributed to fundamentals and $\Delta R P$. This is a significant improvement of approximately $16 \%$ over the fundamental model alone, as reported above the diagonal in Panel B. Interestingly, $\triangle \mathrm{RP}$ explains the largest percentage of the increase in covariance for high-credit-quality portfolios even though the change in exposures was small. Hence, the higher percentages likely illustrate the importance of an increase in factor variance-covariance, which is confirmed by holding $\Sigma_{\tau}$ constant over the full sample period. In this case, the change in betas alone accounts for only $15 \%$ rather than $40 \%$ of the average increase in covariance across portfolio pairs.

Finally, I reestimate the fundamental model with controls for both liquidity and $\Delta R P$. Using predicted values from the regressions, I calculate the percentage of the increase in covariance explained by the model. These results are reported in Panel $\mathrm{C}$ of Table 6 and show that controlling for liquidity and $\triangle \mathrm{RP}$ captures $22 \%$ more of the increase in sample covariance than the fundamental model alone. However, under the current specification, fundamentals, liquidity, and the default risk premium explain only $50 \%$ of the increase in covariance in the crisis, at best.

\footnotetext{
${ }^{18}$ Projecting onto bond index returns also addresses the concern that $\triangle \mathrm{RP}$ captures a CDS market or index specific effect. Similarly, albeit weaker, results hold when RP is estimated using TRACE bond yield spreads instead of CDS spreads. Additional details are provided in the Appendix.
} 
In Panel A of Table 6, "Precrisis" reports SUR regression coefficients for the default risk premium over the precrisis subperiod (Mar. 1, 2006-July 30, 2007). The dependent variable is the change in the CDS spread of the EDF-sorted portfolio. Fundamental variables are included but not reported. All variables are in basis points. "Marginal Crisis Effects" shows the change in regression coefficients over the crisis subperiod (July 31, 2007-Mar. 9, 2009) obtained by reestimating the SUR regressions over the crisis subperiod and subtracting crisis and precrisis coefficients. The $p$-value for the Wald test of each cross-equation restriction is reported in square brackets. Z-statistics for SUR coefficients are reported in parentheses. Panel B reports the percentage of the increase in covariance explained by the model $\left(\Delta \widehat{\operatorname{cov}}(i, j)_{\text {model }} / \Delta \widehat{\operatorname{cov}}(i, j)_{\text {sample }}\right)$, where $\widehat{\operatorname{cov}}(i, j)_{\tau \text {,model }}=\hat{\beta}_{\tau, j} \hat{\Sigma}_{\tau} \hat{\beta}_{\tau, j}^{\prime}$, and $\Delta$ represents the difference between crisis and precrisis covariance below the diagonal. Above the diagonal, I report marginal contribution from $\Delta$ RP. I use a simple nonparametric bootstrap with replacement and percentile confidence intervals $(1,000$ repetitions) to determine whether the ratio is significantly different from $0 .{ }^{*},{ }^{* *}$, and ${ }^{* * *}$ indicate statistical significance at the $10 \%, 5 \%$, and $1 \%$ levels, respectively.

Panel A. Risk Premium Regressions

\begin{tabular}{|c|c|c|c|c|c|}
\hline & 1 (Low EDF) & 2 & 3 & 4 & 5 (High EDF) \\
\hline $\begin{array}{l}\text { Precrisis } \\
\Delta \mathrm{RP}\end{array}$ & $\begin{array}{l}8.7970^{* * *} \\
(12.91)\end{array}$ & $\begin{array}{l}12.8467^{\text {}} \\
(13.30)\end{array}$ & $\begin{array}{l}13.9045^{\star \star \star *} \\
(12.83)\end{array}$ & $\begin{array}{l}18.4663^{\star \star \star} \\
(14.17)\end{array}$ & $\begin{array}{l}24.1259^{\star \star \star} \\
(12.29)\end{array}$ \\
\hline $\begin{array}{l}\text { Marginal Crisi } \\
\Delta \mathrm{RP}\end{array}$ & $\begin{array}{l}1.9716 \\
{[0.14]}\end{array}$ & $\begin{array}{l}3.5545^{\star} \\
{[0.05]}\end{array}$ & $\begin{array}{l}8.3386^{* \star *} \\
{[0.00]}\end{array}$ & $\begin{array}{l}13.2969^{\star \star \star} \\
{[0.00]}\end{array}$ & $\begin{array}{l}24.5266^{* * *} \\
{[0.00]}\end{array}$ \\
\hline $\begin{array}{l}R^{2} \text { Pre } \\
R^{2} \text { Post }\end{array}$ & $\begin{array}{l}0.4562 \\
0.3956\end{array}$ & $\begin{array}{l}0.5052 \\
0.4081\end{array}$ & $\begin{array}{l}0.4743 \\
0.4243\end{array}$ & $\begin{array}{l}0.5578 \\
0.4416\end{array}$ & $\begin{array}{l}0.5370 \\
0.4250\end{array}$ \\
\hline \multicolumn{6}{|c|}{ Panel B. Ratio of Change in Covariance } \\
\hline $\begin{array}{l}1 \text { (Low EDF) } \\
2 \\
3 \\
4 \\
5 \text { (High EDF) }\end{array}$ & $\begin{array}{l}0.41^{\star \star *} \\
0.41^{\star \star *} \\
0.41^{\star \star \star} \\
0.43^{\star \star \star}\end{array}$ & $\begin{array}{c}2 \\
0.18^{\star \star \star} \\
0.40^{\star \star \star} \\
0.39^{\star \star \star} \\
0.40^{\star \star \star}\end{array}$ & $\begin{array}{c}3 \\
0.19^{\star * \star} \\
0.18^{\star \star \star} \\
0.38^{\star * *} \\
0.39^{\star * \star}\end{array}$ & $\begin{array}{c}4 \\
0.17^{\star \star \star} \\
0.16^{\star \star \star} \\
0.16^{\star \star \star} \\
0.37^{\star \star \star}\end{array}$ & $\begin{array}{c}5 \text { (High EDF) } \\
0.17^{\star \star \star} \\
0.15^{\star \star \star} \\
0.15^{\star \star \star} \\
0.12^{\star \star \star}\end{array}$ \\
\hline \multicolumn{6}{|c|}{ Panel C. Ratio of Change in Covariance with Risk Premium and Liquidity Controls } \\
\hline & 1 (Low EDF) & 2 & 3 & 4 & 5 (High EDF) \\
\hline $\begin{array}{l}1 \text { (Low EDF) } \\
2 \\
3 \\
4 \\
5 \text { (High EDF) }\end{array}$ & $\begin{array}{l}0.47^{\star \star \star} \\
0.46^{\star \star \star} \\
0.48^{\star \star \star} \\
0.50^{\star \star \star}\end{array}$ & $\begin{array}{l}0.25^{\star \star \star} \\
0.44^{\star \star \star} \\
0.46^{\star \star \star} \\
0.47^{\star \star \star}\end{array}$ & $\begin{array}{l}0.24^{\star \star \star} \\
0.22^{\star \star \star} \\
0.43^{\star \star \star} \\
0.43^{\star \star \star}\end{array}$ & $\begin{array}{l}0.24^{\star \star \star} \\
0.22^{\star \star \star} \\
0.20^{\star \star \star} \\
0.43^{\star \star \star}\end{array}$ & $\begin{array}{l}0.24^{\star \star \star} \\
0.21^{\star \star \star} \\
0.19^{\star \star \star} \\
0.18^{\star \star \star}\end{array}$ \\
\hline
\end{tabular}

Turning once again to VaR, I find that controlling for the default risk premium yields an increase in average model-implied VaR of $\$ 25,764$ compared with $\$ 1,053$ if the covariance structure had remained constant at its precrisis level. Combining liquidity and the default risk premium pushes the increase in average model-implied VaR to $\$ 28,245$ per $\$ 10 \mathrm{M}$ of notional value, which is still well short of the $\$ 43,293$ increase in average sample VaR.

\section{B. Robustness}

One may argue that RP captures a component of liquidity risk that is understated by the conventional proxies employed in the previous analysis. To address this concern, I obtain weekly (Wednesday) observations on the size of the assetbacked commercial paper market (SAB), net dealer funding (NDF), and failures to deliver collateral on repo agreements (FAIL) reported to the New York Federal Reserve by registered primary dealers. These data likely contain useful information about dealer funding constraints (SAB and NDF) and market liquidity (FAIL) (see Adrian et al. (2013), Longstaff (2010), and Adrian and Fleming (2005)). 
In addition, I relate $\Delta \mathrm{RP}$ to changes in risk aversion and losses at financial institutions, which likely determine the market price of default risk (see Berndt et al. (2008)). I employ the weekly (median daily) VIX index level from the Chicago Mercantile Exchange to proxy for the risk appetite of market participants. Weekly prices for the on-the-run AAA ABX.HE index, from Markit (ABX), proxy for financial intermediary wealth. The ABX index was widely used as a benchmark for mark-to-market valuation of subprime mortgage portfolios and securitizations (see Stanton and Wallace (2011)). Specifically, I focus on the AAA tranche because it was likely the most widely held by financial institutions because of its high yield, regulatory benefit, and availability. A positive (negative) relationship between $\triangle \mathrm{RP}$ and VIX (ABX) supports the risk premium interpretation.

Results from ordinary least squares (OLS) regressions of the weekly change in RP on the weekly change/return in liquidity, risk aversion, and loss variables are reported in Table 7. The coefficients on VIX and ABX are significant at the $1 \%$ level and are consistent with the default risk premium interpretation. In contrast, there is no evidence that changes in the default risk premium are significantly related to changes in measures of funding or market liquidity.

Next, I consider alternative variable specifications; these findings show that the results in Sections III-VI are robust to the definition of fundamentals. The analysis is unreported for brevity but shows that substituting the fundamental model with the Acharya and Johnson (2007) or Schaefer and Strebulaev (2008) specification, augmenting the model with lagged fundamental variables (up to 5 periods), and including squared/cubed risk-free rates yield similar results. Additionally, I repeat the tests after removing stale prices and find no notable change in the results.

These findings support the existing results. However, it is important to acknowledge that unexplored changes in distribution parameters may have

\section{TABLE 7}

Risk Premium Robustness

Table 7 reports the results for OLS regressions of the weekly change in the estimated default risk premium $(\Delta R P)$ on weekly changes in measures of liquidity, risk aversion, and losses at financial institutions. Liquidity proxies include the size of the asset-backed commercial paper market (SAB), failures to deliver on corporate fixed-income repo agreements (FAIL), and net dealer funding (NDF) from the New York Federal Reserve. The VIX index (VIX) and ABX index return (ABX) measure risk aversion and large losses at financial institutions, respectively. The ABX index return is the percentage of change in the upfront spread for the AAA index. $t$-statistics, calculated using Huber-White robust standard errors, are reported in parentheses. ${ }^{*},{ }^{\star *}$, and ${ }^{* * *}$ indicate statistical significance at the $10 \%, 5 \%$, and $1 \%$ levels, respectively.

\begin{tabular}{|c|c|c|c|c|c|c|}
\hline & 1 & 2 & 3 & 4 & 5 & 6 \\
\hline Constant & $\begin{array}{c}0.01 \\
(1.05)\end{array}$ & $\begin{array}{c}0.01 \\
(1.12)\end{array}$ & $\begin{array}{c}0.01 \\
(1.12)\end{array}$ & $\begin{array}{c}0.01 \\
(0.88)\end{array}$ & $\begin{array}{c}0.00 \\
(0.02)\end{array}$ & $\begin{array}{c}0.00 \\
(-0.02)\end{array}$ \\
\hline$\triangle \mathrm{SAB}$ & $\begin{array}{c}0.00 \\
(-1.33)\end{array}$ & & & & & $\begin{array}{c}0.00 \\
(-1.53)\end{array}$ \\
\hline$\Delta \mathrm{FAIL}$ & & $\begin{array}{c}0.00 \\
(-0.32)\end{array}$ & & & & $\begin{array}{c}0.00 \\
(0.29)\end{array}$ \\
\hline$\Delta \mathrm{NDF}$ & & & $\begin{array}{c}0.00 \\
(-0.63)\end{array}$ & & & $\begin{array}{c}0.00 \\
(-0.89)\end{array}$ \\
\hline$\Delta \mathrm{VIX}$ & & & & 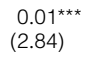 & & $\begin{array}{l}0.01^{\star \star} \\
(2.26)\end{array}$ \\
\hline ABX & & & & & $\begin{array}{l}-0.91^{\star \star \star} \\
(-3.18)\end{array}$ & $\begin{array}{l}-0.67^{\star \star \star \star} \\
(-2.43)\end{array}$ \\
\hline $\begin{array}{l}\text { Adj. } R^{2} \\
N\end{array}$ & $\begin{array}{r}0.0020 \\
156\end{array}$ & $\begin{array}{r}-0.0058 \\
156\end{array}$ & $\begin{array}{r}-0.0018 \\
156\end{array}$ & $\begin{array}{r}0.1963 \\
156\end{array}$ & $\begin{array}{r}0.1928 \\
156\end{array}$ & $\begin{array}{r}0.2898 \\
156\end{array}$ \\
\hline
\end{tabular}


influenced the estimated change in correlation/covariance in the crisis (see Aitkin (1964)). In the following section, I investigate the effect of time-varying parameters, which may help address this concern.

\section{Time-Varying Exposures}

This section extends the methodology to consider time-varying parameters. To operationalize the analysis, I compare each of the previously described variable specifications with exposures estimated over the monthly, quarterly, and precrisis/crisis horizons. Following Bekaert et al. (2009), I employ the covariance mean squared error (CMSE) to evaluate the relative performance of each model in capturing the covariance structure of the data. ${ }^{19}$

A subset of these results is reported in Table 8. Panel A investigates the importance of time-varying betas for the same variable specification. For instance, row 1 compares the relative performance of constant, quarterly, and monthly beta estimates for the fundamental model specification. The 0.30 reported in column 1 suggests that quarterly beta estimates offer a stronger fit to the sample covariance structure than monthly beta estimates prior to the crisis.

In general, these results show that time-varying exposures, beyond a single shift, significantly contribute to the changes in covariance over the sample period. Columns 1 and 2 (4 and 5) show that quarterly and monthly time-varying betas significantly improve the fit of model-implied covariance relative to the constant beta model, respectively, prior to (during) the crisis across all variable specifications. Columns 7 and 8 confirm that this result holds for the change in covariance structure as well.

In addition, column 3 of Table 8 shows that quarterly variation in betas outperformed monthly variation. This suggests that under normal economic conditions, the loss in parameter stability outweighs the benefit of high-frequency beta estimates. Not surprisingly, this result reverses under economic stress. Column 6 reports an improvement in the fit of model-implied covariance with higher-frequency (monthly) variation in beta. Consequently, the monthly beta model also better captures the increase in covariance across all models, as demonstrated in column 9.

Panel B of Table 8 reports the difference in CMSE for different variable specifications while holding the beta estimation horizon constant. These results largely mirror those for the constant-beta model presented in Section VI. First, the fundamental model underperforms all other specifications in explaining precrisis/crisis covariance levels as well as the change (rows 1-4). Second, with the exception of fundamentals, the counterparty risk model tends to underperform other specifications in explaining the levels and change in covariance (rows 2, 5, 8, and 9).

\footnotetext{
${ }^{19}$ Quarterly exposures are obtained by rolling the SUR estimation over nonoverlapping quarterly windows. The monthly exposure for portfolio $i$ to factor $j$ in month $t$ is $\hat{\beta}_{t, i, j}=\hat{\rho}_{\tau}\left(\hat{\sigma}_{t, \Delta \mathrm{CDS}_{i}} / \hat{\sigma}_{t, F_{j}}\right)$, where $\hat{\rho}_{\tau}$ is the semipartial correlation between factor $j$ and $\Delta \operatorname{CDS}_{i}$ in quarter $\tau$ and $\hat{\sigma}_{t}$ is the volatility in month $t$. Precrisis/Crisis exposures are obtained from SUR estimations over each subperiod.
} 
TABLE 8

\section{Time Varying $\beta$ Mean Squared Error}

Columns 1-6 of Table 8 report the difference in covariance mean squared error $\left(\mathrm{CMSE}_{m_{\mathrm{k}}}-\mathrm{CMSE}_{m_{1}}\right)$ between different model specifications ( $m_{k}$ and $m_{l}$ ) over the precrisis (columns 1-3) and crisis periods (columns 4-6). To obtain $\mathrm{CMSE}_{m_{k}}$, I calculate CMSE over the 10 portfolio combinations each month and average over monthly observations as shown herein. For brevity, I denote $\operatorname{cov}\left(\Delta \mathrm{CDS}_{i}, \Delta \mathrm{CDS}_{j}\right)$ as $\operatorname{cov}(i, j)$ :

$$
\begin{aligned}
\mathrm{CMSE}_{t, m_{k}} & =\frac{1}{10} \sum_{i=1}^{5} \sum_{j=i+1}^{5}\left[\widehat{\operatorname{cov}}(i, j)_{t, \text { sample }}-\widehat{\operatorname{cov}}(i, j)_{t, m_{k}}\right]^{2}, \\
\mathrm{CMSE}_{m_{k}} & =\frac{1}{n} \sum_{t=1}^{n} \mathrm{CMSE}_{t, m_{k}} .
\end{aligned}
$$

I calculate $\mathrm{CMSE}_{m_{k}}$ over each subperiod. Therefore, $n$ equals the number of monthly observations in the precrisis subperiod in columns $1-3$ and the number of monthly observations in the crisis subperiod in columns $4-6 . \widehat{\operatorname{cov}}(i, j)_{t, m_{k}}=$ $\hat{\beta}_{i, \tau, m_{k}} \hat{\Sigma}_{t, m_{k}} \hat{\beta}_{j, \tau, m_{k}}^{\prime}$ is the model-implied covariance between portfolios $i$ and $j$ in month $t$ for model $m_{k}$, where $\tau$ indicates the relevant subperiod, quarter, or month on which beta is estimated and the index $t$ denotes the month. Note that for monthly time-varying betas, $\tau=t$. Columns 7-9 report the difference-in-difference between the CMSEs of the model specifications over the crisis break: $\triangle \mathrm{CMSE}_{m_{k}}-\Delta \mathrm{CMSE}_{m_{l}}$, where $\Delta \mathrm{CMSE}_{m_{k}}=\mathrm{CMSE}_{\text {crisis, } m_{k}}-\mathrm{CMSE}_{\text {precrisis, } m_{k}}$. Panel A compares the performance of constant (C), quarterly $(\mathrm{Q})$, and monthly $(\mathrm{M})$ time-varying $\beta$ s for a fixed-variable specification. The constant-beta model allows for a one-time change in the crisis but holds $\hat{\beta}$ constant over the precrisis and crisis subperiods. Column headers list the model comparison. For example, $(C-Q)$ shows the difference in $(\Delta) C M S E$ between constant and quarterly time-varying beta specifications; a positive value implies that the quarterly beta specification outperforms the constant-beta specification over the indicated subperiod. Panel B compares the $(\Delta)$ CMSE values of different variable specifications with fixed time-varying beta frequencies. Column headers indicate the horizon of beta estimates: constant (C), quarterly $(\mathrm{Q})$, and monthly (M). Row headers show the variable specification comparison. For example, column 2 of row 2 compares the CMSE of the fundamental versus the counterparty risk variable specification with quarterly time-varying betas prior to the crisis. Variable specifications are abbreviated as follows: Fund = fundamentals, $\mathrm{Liq}=$ fundamentals + liquidity variables, $\mathrm{CP}=$ fundamentals + counterparty risk variables, $\mathrm{RP}=$ fundamentals $+\Delta \mathrm{RP}$, $(\mathrm{Liq} \& \mathrm{RP})=$ fundamentals $+\Delta \mathrm{RP}+$ liquidity variables, and $\left(\right.$ Liq \& RP) ${ }^{\star}=$ fundamental $+\Delta R P+$ liquidity variables with 1-period-lagged $\hat{\beta}\left(\hat{\beta}_{t-1}\right)$. In all cases, I use a simple nonparametric bootstrap with replacement and percentile confidence intervals ( 1,000 repetitions) to determine significance. ${ }^{*},{ }^{* *}$, and ${ }^{* * *}$ indicate statistical significance at the $10 \%$, $5 \%$, and $1 \%$ levels, respectively.

\begin{tabular}{|c|c|c|c|c|c|c|c|c|}
\hline & \multicolumn{2}{|c|}{ Precrisis Difference } & \multicolumn{3}{|c|}{ Crisis Difference } & \multicolumn{3}{|c|}{ Difference-in-Difference } \\
\hline & $(C-Q)$ & $(C-M) \quad(Q-M)$ & $(C-Q)$ & $(C-M)$ & $(\mathrm{Q}-\mathrm{M})$ & $(C-Q)$ & $(C-M)$ & $(Q-M)$ \\
\hline and & $0.30^{\star \star \star}$ & $0.05^{\star \star \star}-0.25^{\star \star \star}$ & *** & 181 & *** & $109.08^{\star \star \star *}$ & $9^{\star \star \star \star}$ & $72.71^{\star * *}$ \\
\hline & $0.29^{\star \star \star}$ & $0.01^{\star \star \star}-0.28^{\star \star \star}$ & $359.55^{\star \star \star}$ & $467.77^{\star \star \star}$ & $108.22^{\star \star \star}$ & $359.26^{\star \star \star}$ & $467.76^{\star \star \star}$ & $108.50^{\star \star \star}$ \\
\hline CP & $0.27^{\star \star \star}$ & $0.18^{\star \star \star}-0.09^{\star \star \star}$ & $232.81^{\star \star \star}$ & $304.14^{\star \star \star}$ & $71.33^{\star \star \star}$ & $232.54^{\star \star \star}$ & $303.96^{\star \star \star}$ & $71.42^{\star \star \star}$ \\
\hline & $0.15^{\star \star \star}$ & $0.14^{\star \star \star}-0.01^{\star \star \star}$ & $118.98^{\star \star \star}$ & $279.06^{\star \star \star}$ & $160.09^{\star \star \star}$ & $118.83^{\star \star \star}$ & $278.93^{\star \star \star}$ & $160.10^{\star \star \star}$ \\
\hline Liq \& RP & $0.13^{\star \star \star}$ & $0.12^{\star \star \star}-0.01^{\star \star \star}$ & $193.06^{\star \star \star}$ & $300.52^{\star \star \star}$ & $107.46^{\star \star \star}$ & $192.93^{\star \star \star}$ & $300.40^{\star \star \star}$ & $107.47^{\star \star \star}$ \\
\hline
\end{tabular}

Panel A. Comparison of CMSE between Time-Varying Beta Models with Fixed Variable Specification

\begin{tabular}{|c|c|c|c|c|c|c|c|c|c|}
\hline & \multicolumn{3}{|c|}{ Precrisis Difference } & \multicolumn{3}{|c|}{ Crisis Difference } & \multicolumn{3}{|c|}{ Difference-in-Difference } \\
\hline & C & Q & $\mathrm{M}$ & C & Q & $\mathrm{M}$ & C & Q & M \\
\hline Fund - Liq & $0.04^{\star \star *}$ & $0.03^{\star \star \star *}$ & 0.00 & $68.60^{* * *}$ & $318.77^{\star \star \star}$ & $354.53^{* * *}$ & $68.56^{\star \star \star}$ & $318.74^{* * *}$ & $354.53^{\star * *}$ \\
\hline Fund - CP & $0.003^{\star \star \star}$ & $-0.03^{\star \star \star}$ & $0.13^{\star * *}$ & $30.65^{\star \star *}$ & $154.08^{\star \star \star}$ & $152.95^{\text {*** }}$ & $30.65^{\star * \star *}$ & $154.11^{* * *}$ & $152.82^{* * *}$ \\
\hline Fund - RP & $0.22^{\star \star \star *}$ & $0.04^{\star \star *}$ & $0.30^{\star \star * *}$ & $221.89^{\star \star \star}$ & $231.49^{\star \star \star}$ & $319.11^{* \star *}$ & $221.67^{\star \star \star *}$ & $231.45^{\star * \star *}$ & $318.81^{\star * \star}$ \\
\hline Fund - (Liq \& RP) & $0.25^{\star \star *}$ & $0.04^{\star * * *}$ & $0.32^{\star \star * *}$ & $292.83^{\star * *}$ & $376.51^{\text {***}}$ & $411.50^{* * *}$ & $292.58^{* * *}$ & $376.47^{* * * \star}$ & $411.18^{\star * *}$ \\
\hline $\mathrm{Liq}$ - CP & $-0.04^{\star \star *}$ & $-0.06^{\star \star \star}$ & $0.13^{\star \star * *}$ & $-37.95^{\star * *}$ & $-164.69^{\star \star \star}$ & $-201.58^{\star * *}$ & $-37.91^{\star \star *}$ & $-164.63^{* \star \star}$ & $-201.71^{\star * \star}$ \\
\hline Liq - RP & $0.18^{\star \star \star}$ & $0.00^{\star \star \star \star}$ & $0.30^{\star \star *}$ & $153.29^{\star \star \star}$ & $-87.28^{\star \star \star}$ & $-35.41^{\star \star * \star}$ & $153.12^{\star \star \star *}$ & $-87.29^{\star \star \star \star}$ & $-35.71^{\star \star \star \star}$ \\
\hline Liq - (Liq \& RP) & $0.20^{\star \star \star}$ & 0.00 & $0.32^{\star \star \star}$ & $224.23^{\star \star \star}$ & $57.74^{\star \star \star}$ & $56.98^{\star \star \star *}$ & $224.02^{\star \star \star \star}$ & $57.74^{\star \star \star \star}$ & $56.66^{\star * *}$ \\
\hline $\mathrm{CP}-\mathrm{RP}$ & $0.22^{\star \star \star}$ & $0.07^{\star \star \star}$ & $0.16^{\star \star *}$ & $191.25^{\star \star \star}$ & $77.41^{\star \star \star}$ & $166.17^{\star \star \star \star}$ & $191.03^{\star \star \star}$ & $77.34^{\star \star \star}$ & $166.01^{* * *}$ \\
\hline $\mathrm{CP}-(\mathrm{Liq} \& \mathrm{RP})$ & $0.25^{\star \star \star}$ & $0.07^{\star \star \star}$ & $0.17^{\star * *}$ & $262.18^{\star \star \star}$ & $222.43^{\star \star \star}$ & $258.56^{\star \star \star *}$ & $261.93^{\star \star \star}$ & $222.36^{\star \star \star \star}$ & $258.39^{\star * \star}$ \\
\hline $\mathrm{RP}-(\mathrm{Liq} \& \mathrm{RP})$ & $0.03^{\star \star \star}$ & 0.00 & 0.00 & $70.93^{\star \star *}$ & $145.02^{\star \star \star}$ & $92.39^{\star \star \star *}$ & $70.91^{\star \star \star *}$ & $145.02^{* * *}$ & $92.39^{* * *}$ \\
\hline$($ Liq \& RP $)-(\text { Liq \& RP })^{*}$ & & $-0.49^{\star \star \star}$ & $-0.59^{\star \star \star}$ & & $-60.78^{\star \star *}$ & $-426.66^{\star * *}$ & & $-60.29^{\star * *}$ & $-426.07^{\star \star \star \star}$ \\
\hline
\end{tabular}

Panel B. Comparison of CMSE between Variable Specifications with Fixed Time-Varying Beta Horizons

Third, the default risk premium model tends to outperform the liquidityadjusted model prior to and during the crisis with constant exposures. However, columns 5 and 6 of row 6 in Table 8 show that the relative importance of liquidity is likely understated in the constant-beta model. With the addition of time-varying betas (quarterly or monthly), the liquidity-adjusted model outperforms the risk premium specification during the crisis. 
Finally, the combination of fundamentals, liquidity, and the default risk premium (denoted "(Liq \& RP)") with monthly betas provides the best characterization of both the level and change in covariance structure observed in the data. ${ }^{20}$

Interestingly, Figure 2 shows that during the crisis, sample covariance spiked around extreme events and recovered over the ensuing months. This implies that long-horizon investors may benefit from holding allocations rather than rebalancing to offset short-term jumps in covariance. In contrast, months of increased covariance may result in large losses for short-horizon portfolios such as bank trading books.

Additionally, model-implied covariance closely tracks sample covariance up to the Lehman Brothers' failure. This confirms that fundamentals, liquidity risk, and the default risk premium along with time-varying betas provide a strong representation of the covariance structure between portfolio CDS spread changes. The notable exception is under extreme economic distress, which is related to the Lehman Brothers' event in this case. ${ }^{21}$

Finally, accounting for time-varying exposures increased the change in model-implied VaR to $\$ 36,036$ compared with $\$ 1,909$ for the counterfactual VaR.

\section{FIGURE 2}

\section{Average Monthly Covariance}

Figure 2 shows the evolution of average model-implied covariance and average sample covariance each month over the sample period. To obtain the average model-implied covariance, I calculate $\hat{\beta}_{i, t} \hat{\Sigma}_{t} \hat{\beta}_{j, t}^{\prime}$ each month and average over the 10 portfolio $(i, j)$ combinations. Similarly, the average sample covariance is the average covariance between portfolio CDS spread changes over the 10 portfolio combinations each month. The right axis shows the ratio of average modelimplied to average sample covariance each month. Note that the units for covariance, graphed on the $y$-axis, are basis points squared.

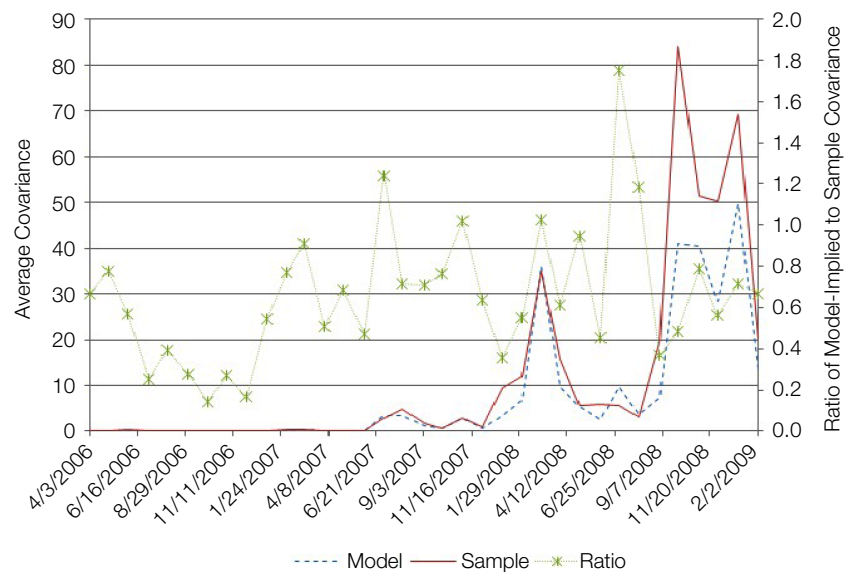

\footnotetext{
${ }^{20}$ One may object to the use of contemporaneous exposures. Therefore, I replace $\hat{\beta}_{t}$ with $\hat{\beta}_{t-1}$ in the final model (denoted "(Liq \& RP)") and compare their performance. These results, reported in the last row of Panel B in Table 8, show that lagged betas significantly underperformed contemporaneous betas, especially during the crisis. However, the underperformance is almost exclusively related to extreme unexpected events such as the hedge fund crisis and Lehman Brothers' failure.

${ }^{21} \mathrm{~A}$ simple $t$-test for equality between model and sample covariance prior to Sept. 2008 fails to reject the null.
} 
This is a substantial improvement over the constant-beta model but still $\$ 7,257$ short of explaining the full change in sample VaR.

From this analysis, it is apparent that time variation in factor exposures as well as factor variances played an important role in amplifying covariance during the crisis.

Next, I investigate the contribution from time-varying $\beta$ versus $\Sigma$ to the increase in covariance. Given the previous results, I focus on the monthly timevarying beta model with controls for fundamentals, liquidity, and $\Delta \mathrm{RP}$.

To implement the analysis, I calculate the monthly sample and modelimplied covariance for each portfolio combination. Next, I average monthly observations to obtain estimates of the conditional model-implied and sample covariance for each portfolio combination over the precrisis and crisis subperiods. For example, I estimate the crisis conditional covariance between the CDS spread changes of portfolios $\mathrm{i}$ and $\mathrm{j}$ as follows: $\widehat{\operatorname{cov}}(i, j)_{\text {crisis }, k}=1 / n \sum_{\mathrm{t}=1}^{n} \widehat{\operatorname{cov}}(i, j)_{t, k}$, where $n$ equals the number of monthly covariance observations over the crisis subperiod, and $k=$ \{model, sample $\}$. The percentage of the increase in covariance captured by the model is as follows:

$$
R_{i, j}=\frac{\Delta \widehat{\operatorname{cov}}(i, j)_{\text {model }}}{\Delta \widehat{\operatorname{cov}}(i, j)_{\text {sample }}}
$$

where $\Delta \widehat{\operatorname{cov}}(i, j)_{k}$ is the increase in conditional covariance: $\widehat{\operatorname{cov}}(i, j)_{\text {crisis }, k}-$ $\widehat{\operatorname{cov}}(i, j)_{\text {precrisis }, k}$.

Next, in the spirit of Ferson and Harvey (1991), I investigate how much of the increase in covariance is driven by time-varying exposures compared with time-varying factor variance-covariance. To disentangle the two effects, I hold $\hat{\Sigma}_{t}$ constant at its unconditional mean $\left(\mathrm{E}[\hat{\Sigma}]=1 / N \sum_{\mathrm{t}=1}^{N} \hat{\Sigma}_{t}\right)$ and recalculate the time series of model-implied covariance $\left(\hat{\beta}_{i, t} \mathrm{E}[\hat{\Sigma}] \hat{\beta}_{j, t}^{\prime}\right)$. This time series yields insight into the relative importance of time-varying betas. Similarly, repeating the calculation using unconditional betas $\left(\mathrm{E}\left[\hat{\beta}_{i}\right]=1 / N \Sigma_{\mathrm{t}=1}^{N} \hat{\beta}_{i, t}\right)$ yields a time series of model-implied covariance $\left(\mathrm{E}\left[\hat{\beta}_{i}\right] \hat{\Sigma}_{t} \mathrm{E}\left[\hat{\beta}_{j}\right]^{\prime}\right)$ that provides useful information on the relative importance of time-varying $\hat{\Sigma}_{t}$, where $N$ equals the total number of monthly observations in the sample.

Finally, I calculate $R_{i, j}$, described previously, for the time series of modelimplied covariance calculated using unconditional betas and again using unconditional factor variance-covariance. These results are reported in Table 9. Column 1 shows that with the addition of time-varying $\hat{\beta}_{t}$ and $\hat{\Sigma}_{t}$, the model captures $66 \%$ of the increase in covariance in the crisis, which is a marked improvement over the more static model presented in Panel C of Table 6.

Moreover, columns 2 and 3 of Table 9 suggest that time variation in both $\hat{\beta}_{t}$ and $\hat{\Sigma}_{t}$ contributed significantly to the increase in covariance. However, the magnitude of the contribution from variation in $\hat{\beta}_{t}$ far outweighed that of $\hat{\Sigma}_{t}$. Holding $\hat{\Sigma}_{t}$ constant at its unconditional mean (column 2), time variation in $\hat{\beta}_{t}$ captures, on average, $50 \%$ of the increase in sample covariance. In contrast, the model only explains $24 \%$, on average, of the increase in sample covariance when $\hat{\beta}_{t}$ is held constant at its unconditional mean (column 3). 
Table 9 tabulates the percentage of the change in sample covariance captured by the model. This table presents results for the model with controls for changes in fundamentals, liquidity, and the default risk premium with monthly time-varying beta. Ratios are listed in column headers; $\Delta \widehat{\operatorname{COV}}(i, j)=1 / n_{c} \sum_{t=1}^{n_{c}} \widehat{\operatorname{COV}}(i, j)_{t}-1 / n_{p} \sum_{t=1}^{n_{p}} \widehat{\operatorname{COV}}(i, j)_{t}$, where $\widehat{\operatorname{COV}}(i, j)_{t}$ is the sample/model-implied covariance between portfolios $i$ and $j$ CDS spread changes in month $t$; and $n_{p}$ and $n_{c}$ are the number of months in the precrisis and crisis subperiods, respectively. In column 1 , I report the fraction calculated using model-implied covariance with monthly time-varying $\hat{\beta}_{t}$ and $\hat{\Sigma}_{t}$. Column 2 reports the fraction with model-implied covariance calculated using monthly $\hat{\beta}_{t}$ and unconditional factor variance-covariance $\left(E[\hat{\Sigma}]=1 / N \sum_{t=1}^{N} \hat{\Sigma}_{t}\right)$, where $N$ equals the total number of months in the sample. Column 3 reports the fraction with model-implied covariance calculated using monthly time-varying $\hat{\Sigma}_{t}$ and unconditional exposures $\left(E\left[\hat{\beta}_{i}\right]=1 / N \sum_{t=1}^{N} \hat{\beta}_{i, t}\right)$. In all cases, I use a simple nonparametric bootstrap with replacement and percentile confidence intervals (1,000 repetitions) to determine significance. ${ }^{*},{ }^{* *}$, and ${ }^{* * *}$ indicate statistical significance at the $10 \%, 5 \%$, and $1 \%$ levels, respectively.

\begin{tabular}{|c|c|c|c|}
\hline & $\Delta \widehat{\operatorname{cov}}(i, j)_{\text {model }}$ & $\Delta \mathrm{E}\left[\hat{\beta}_{i, t} \mathrm{E}[\hat{\Sigma}] \hat{\beta}_{j, t}^{\prime}\right]$ & $\Delta \mathrm{E}\left[\mathrm{E}\left[\hat{\beta}_{i}\right] \hat{\Sigma}_{t} \mathrm{E}\left[\hat{\beta}_{j}\right]^{\prime}\right.$ \\
\hline & $\underline{\Delta \operatorname{cov}}(i, j)_{\text {sample }}$ & $\Delta \widehat{\operatorname{Cov}}(i, j)_{\text {sample }}$ & $\Delta \widehat{\operatorname{cov}}(i, j)_{\text {sample }}$ \\
\hline $\mathrm{R}_{1,2}$ & $0.66^{\star \star \star}$ & $0.51^{\star \star \star}$ & $0.25^{\star \star \star}$ \\
\hline $\mathrm{R}_{1,3}$ & $0.72^{\star \star \star}$ & $0.66^{\star \star \star}$ & $0.26^{\star \star *}$ \\
\hline $\mathrm{R}_{1,4}$ & $0.67^{\star \star \star}$ & $0.51^{\star \star \star}$ & $0.25^{\star \star \star}$ \\
\hline $\mathrm{R}_{1,5}$ & $0.68^{\star \star \star}$ & $0.57^{\star \star \star}$ & $0.28^{\star \star *}$ \\
\hline $\mathrm{R}_{2,3}$ & $0.67^{\star \star \star}$ & $0.52^{\star \star \star}$ & $0.25^{\star * *}$ \\
\hline $\mathrm{R}_{2,4}$ & $0.64^{\star \star \star}$ & $0.40^{\star \star \star}$ & $0.24^{* * *}$ \\
\hline $\mathrm{R}_{2,5}$ & $0.64^{\star \star \star}$ & $0.48^{\star \star \star}$ & $0.25^{\star \star \star}$ \\
\hline $\mathrm{R}_{3,4}$ & $0.68^{\star \star \star}$ & $0.47^{\star \star \star}$ & $0.24^{\star \star \star}$ \\
\hline $\mathrm{R}_{3,5}$ & $0.69^{\star \star \star}$ & $0.57^{\star \star \star}$ & $0.24^{\star \star \star}$ \\
\hline $\mathrm{R}_{4,5}$ & $0.64^{\star \star \star}$ & $0.47^{\star \star \star}$ & $0.23^{\star \star *}$ \\
\hline Rooled & $0.66^{\star \star \star}$ & $0.50^{\star \star *}$ & $0.24^{* * *}$ \\
\hline
\end{tabular}

\section{Conclusion}

Using a set of 159 liquid CDS contracts, I document an increase in the commonality between CDS spread changes over the 2007-2009 financial crisis. To better understand why commonality increased, I aggregate to EDF-sorted quintile portfolios and decompose the increase in covariance between portfolio CDS spread changes into fundamental and excess components. ${ }^{22}$ I find that only $23 \%$ of the increase in covariance was driven by changes in the fundamental determinates of credit risk. The remainder can largely be attributed to changes in liquidity and the default risk premium. In contrast, counterparty risk had no impact on the change in covariance.

Further analysis shows that covariance varied substantially during the crisis. In general, this variation can be attributed to changes in fundamentals, liquidity, and the default risk premium with monthly time-varying exposures. However, in the 6 months following the failure of Lehman Brothers, covariance spiked beyond what could be explained by the model. These results have important implications for regulation, pricing, and portfolio allocation.

Recent reform of banking regulations has highlighted the importance of changes in commonality, especially in times of crisis. For example, Basel III introduced specific capital charges for "stressed" VaR and correlation trading portfolios, calling for 12 months of historical data in the VaR calculation. The results presented herein suggest that the estimation window may be an important consideration in adequately capitalizing credit derivative trading books under economic distress. Moreover, capital held against stressed VaR for CDS contracts

\footnotetext{
${ }^{22}$ I decompose the increase in covariance by estimating a linear factor model in a system of SURs with covariates commonly used to characterize credit risk (see Collin-Dufresne et al. (2001)).
} 
and for correlation trading portfolios will likely combine charges for both creditand noncredit-related covariance.

At the same time, even small unexpected changes in covariance can have large ramifications for portfolio allocation (see Kandel and Stambaugh (1996)). The increase in covariance illustrated herein suggests that reallocating to accommodate a higher base level of covariance may be beneficial for prolonged periods of economic uncertainty. However, large changes in covariance linked to extreme events are likely short-lived. Therefore, investors may incur unnecessary costs by reallocating to offset large short-term changes in covariance. In either case, it is prudent to consider the sources of increased covariance in the reallocation decision.

In summary, this paper provides an important first look at changes in the commonality between CDS spreads under economic distress. The results reported within have broad implications for the future trading and regulation of CDS contracts.

\section{Appendix. Variable Definitions}

\section{Fundamental Variables}

RF3M The 3-month constant-maturity Treasury rate (CMTR) from the Federal Reserve H.15 release (daily). This variable captures the risk-neutral drift in the Merton model. In this context, an increase in RF3M reduces the cost of the put option purchased by bondholders, which increases the value of debt and decreases the yield spread. Therefore, I expect changes in RF3M to be negatively related to CDS spread changes.

SLOPE The slope of the yield curve, calculated as the difference between the 5-year and 3-month (5-year CMTR - RF3M) constant-maturity Treasury rate from the Federal Reserve H.15 release. Larger SLOPE implies an expected increase in the future riskfree rate. Applying the same logic from RF3M, I would expect the change in SLOPE to be negatively related to CDS spread changes.

SP500 The daily holding period return for the S\&P 500 index from CRSP. This variable is a general measure of economic conditions. In a strong economy, one would expect the S\&P 500 index to yield higher returns. At the same time, corporate bond yield spreads would likely be lower due to lower default probabilities and higher expected recovery. Therefore, I expect S\&P 500 returns to be negatively related to CDS spread changes.

SPVOL GARCH volatility for the S\&P 500 return from CRSP. The daily conditional standard deviation of S\&P 500 equity returns obtained from a generalized autoregressive conditional heteroskedastic (ARMA-GARCH) model specification: ARMA $(1,1)$ GARCH(1,1). S\&P 500 volatility measures market-wide uncertainty. As a result, I would expect changes in SPVOL to be positively related to CDS spread changes.

HB A value-weighted index of equity returns for major U.S. home builders (Standard Industrial Classification (SIC) code 1521) obtained from CRSP. The index is used to capture housing market conditions at a high frequency. Poor housing market conditions, especially between 2007 and 2009, are likely associated with higher corporate bond yields. Hence, I expect a negative relationship between CDS spread changes and HB. This index is highly correlated with the S\&P 500 return; therefore, I orthogonalize with respect to SP500 and focus on its relative effect. 
DEF The default spread, which is the difference in yield between Moody's Aaa and Baa indices from the Federal Reserve Board H.15 release. The default spread measures general credit market conditions (see Fama and French (1993), Gilchrist and Zakrajsek (2012)). Larger spreads can reflect a preference for quality or a general deterioration in the creditworthiness of Baa relative to Aaa issuers. Because the default spread is measured in yield, I would expect changes to be positively associated with changes in CDS spreads.

SMB The small cap equity factor as described by Fama and French (1993) obtained from Kenneth French's Web site (http://mba.tuck.dartmouth.edu/pages/faculty/ ken.french/data_library.html). This variable has been used in several papers as a state variable. Additionally, authors have argued that it may proxy for credit risk (see Vassalou and Xing (2004)). In either case, I expect a negative relationship between SMB and CDS spread changes.

HML The high-minus-low (value) equity factor as described by Fama and French (1993) obtained from Kenneth French's Web site (http://mba.tuck.dartmouth.edu/ pages/faculty/ken.french/data_library.html). Justification is the same as that for SMB. Again, I expect HML to be negatively related to CDS spread changes.

PORTRET The equal-weighted equity return for EDF-sorted portfolios from CRSP. These returns are constructed in the same manner as portfolio CDS spread changes. On the last day of each month, firms are sorted into quintile portfolios based on their EDF values. For each day of the subsequent month, I average holding period returns over firms in each quintile. Portfolio returns are highly correlated with the S\&P 500 return. Therefore, I orthogonalize portfolio equity returns with respect to the S\&P 500 return and focus on their marginal contributions. Portfolio equity returns provide a high-frequency measure of average leverage (negative equity returns increase leverage). Therefore, equity returns should be negatively related to CDS spread changes.

PORTVOL The daily conditional standard deviation of PORTRET obtained from an ARMA-GARCH model. The Merton model theoretically links equity volatility to default risk. Therefore, the change in portfolio return volatility may contain useful information for explaining CDS spread changes. Because equity volatility measures risk, I expect changes in PORTVOL to be positively related to CDS spread changes. Mostly, an ARMA(1,1)-GARCH(1,1) specification sufficiently fits returns.

\section{Liquidity Variables}

OISTB The difference between the overnight index swap rate (OISR) obtained from Datastream and RF3M, which captures the liquidity component of the TED spread. The TED spread equals 3-month London Interbank Offered Rate (LIBOR) less RF3M and increases with the level of counterparty risk and liquidity risk in the banking system. Eichengreen et al. (2012) argue that the OISR can be used to disentangle these effects.

OISTB is positively related to illiquidity. This is because overnight index swaps do not require the exchange of principal. Therefore, OISR should be invariant to counterparty risk. However, OISR will vary with liquidity risk because it is based on the federal funds rate, which increases when banks become liquidity constrained.

ONOFF The yield difference between the on-the-run and most recent off-the-run 5-year Treasury note obtained from Datastream. The on-the-run Treasury note is the most liquid. Therefore, the yield gap between this bond and the closest maturity-matched Treasury note measures market liquidity. Larger values of ONOFF relate to higher liquidity premiums. 
ONREPO The spread between RF3M and the 3-month general collateral U.S. government repo rate obtained from Bloomberg. Liu et al. (2006) argue that the general collateral referenced in these contracts is less liquid than the on-the-run securities used to calculate the constant-maturity Treasury rates. Moreover, repurchase agreements are contracts and likely less subject to specialness effects. Similar to ONOFF, ONREPO increases with market illiquidity.

VOLUME The average daily principal traded each day over representative (average) bonds issued by each firm in the sample obtained from TRACE. To construct the measure, I sum the principal (in millions) traded on each day for each bond issued by a firm in the sample. Next, I average up to the firm level. Finally, I average across firms to obtain the final VOLUME index. I drop convertibles, floatingrate notes, bonds denominated in foreign currency, sinking funds, asset-backed securities, mortgage-backed securities, preferred securities, unit deals, warrants, and bonds with more than 7 years or less than 3 years to maturity to calculate all bond liquidity measures. Weighted average liquidity measures that account for the number of bonds issued by each firm yield similar results.

NTRADE The average number of reported trades for each firm's representative bonds each day in TRACE. Again, I sum the total number of trades on each day for each bond issued by a firm in the sample and average up to the firm level. Next, I average across firms to obtain the final NTRADE index. I employ the same filters used in VOLUME for NTRADE.

AMIHUD Average bond Amihud measure from TRACE. The average Amihud measures price impact over all firms' representative bonds in the sample. Daily Amihud $\left(1 / N_{t} \sum_{t=1}^{N_{t}}\left|\left(P_{t}-P_{t-1}\right) / P_{t-1}\right| / Q_{t}\right)$ is calculated for each bond issued by a company in the sample, where $P_{t}$ is the clean price, $Q_{t}$ is volume in millions, and $N_{t}$ is the number of return observations per day (a bond must trade at least two times in a day to calculate Amihud). These series are averaged up to the firm level and then across firms to obtain the daily Amihud index.

BIDASK Average CDS bid-ask spread from CMA; the average difference between bid and ask CDS spread quotes. CMA provides daily bid and ask quotes for each contract. Taking the difference between these quotes yields a bid-ask spread for each firm-day in the sample. To obtain the average change in bid-ask spread, I winsorize changes on each day at the $95 \%$ level and average bid-ask spread changes over all 159 contracts. This yields the final series $\triangle$ BIDASK.

PORTBA The equal-weighted average portfolio bid-ask spread from CMA. As with portfolio CDS spreads, firms are sorted into quintiles based on their end-of-month EDF values. On each day of the subsequent month, I winsorize bid-ask spread changes at the $95 \%$ level and average over contracts in each quintile to obtain the series $\triangle$ PORTBA. Portfolio bid-ask spreads are highly correlated with BIDASK. Therefore, I orthogonalize each series with respect to the average bid-ask spread and investigate their relative effects.

VRATIO The ratio of daily volume traded in high-volatility to low-volatility stocks from CRSP. Each month, I sort stocks in the CRSP universe into deciles according to the volatility of daily returns in the preceding month. Next, I calculate the ratio of stock volume traded on each day for the average firm in the 10th decile to the average firm in the 1 st decile. When funding constraints bind, investors are more likely to sell highvolatility (high-margin) assets (see Ben-David et al. (2012)). Therefore, the ratio will increase as funding constraints bind. 
BAB The betting-against-beta stock return from CRSP. The BAB factor takes leveraged long positions in low-beta securities and short positions in high-beta securities (see Frazzini and Pedersen (2013)). I estimate market betas for each stock in CRSP on June of each year using 60 months of trailing returns (24 months minimum) as outlined by Fama and French (1992). Following Adrian et al. (2013), I then sort stocks into deciles based on beta, compute equal-weighted daily excess returns, and rescale portfolios to have a beta of 1 . The BAB spread is the difference between excess returns for the 1st and 10th decile portfolio (10th - 1st). According to Frazzini and Pedersen (2013), constrained investors prefer high-beta assets to leveraging low-beta assets, which produces a spread that increases with funding constraints.

LMP Daily returns for a portfolio constructed to mimic aggregate dealer leverage. Adrian et al. (2013) argue that dealer leverage is priced in the cross section of stock returns because it relates to funding constraints. Following their procedure, I use daily returns for the Fama and French (1993) 6-factor portfolios from Kenneth French's Web site (http://mba.tuck.dartmouth.edu/pages/faculty/ken.french/ data_library.html) and the exposures reported in their paper to obtain LMP. Leveragemimicking returns are positively related to dealer funding constraints.

\section{Counterparty Risk Variables}

OIS The difference between 3-month LIBOR, from the British Bankers Association, and the 3-month overnight index swap rate. Interbank lending at LIBOR requires a commitment of principal. Consequently, LIBOR will increase with the likelihood that banks fail to repay their loans. In contrast, overnight index swaps do not require the exchange of principal. Therefore, the overnight index swap spread measures the general confidence that bank-to-bank loans will be repaid. It increases with counterparty risk.

ABCP The difference between the yield on 90-day asset-backed commercial paper, from Bloomberg, and RF3M. It measures the ability of financial institutions to roll over day-to-day obligations in the asset-backed commercial paper market. ABCP increases with counterparty risk.

CPSTOCK The daily value-weighted stock return for a portfolio of major CDS dealers. I define major dealers as the 16 banks licensed by Markit, the index administrator, to make a market for the CDX.NA.IG index. Dealer stock returns provide information on their general health as well as market confidence in the dealer sector.

CPDIF The log difference between the maximum and median daily stock return, from CRSP, for the 16 licensed market-makers described previously. CDS protection buyers may incur losses if their counterparty defaults. Therefore, an increase in credit risk dispersion across dealers may lead to an increase in the protection demanded from a small group of high-quality dealers; as a result, these dealers become price-setters. The spread between the maximum and median return provides a coarse measure of credit risk dispersion among dealers. One would expect CDS spreads to increase with dealer risk dispersion.

\section{Default Risk Premium Variables}

RP The default risk premium. This is the ratio of risk-neutral to physical default probabilities, which captures the market price of default risk. Following Berndt et al. (2008), I compare Moody's KMV EDF (physical probability of default) to CDS spreads (riskneutral probability of default) for nonfinancials using the following panel regression: 


$$
\ln \left(\mathrm{CDS}_{i}\right)=\alpha+\beta \ln \left(\mathrm{EDF}_{i}\right)+\sum_{j} \gamma_{j} D_{j}+\mathrm{z}_{i},
$$

where $\mathrm{CDS}_{i}$ is the 5-year CDS spread for company $i ; \beta$ controls for the nonlinear relationship between the yield spread and EDF; $\alpha$ is the intercept; and $D_{j}$ is a dummy variable that equals 1 on day 1 of the sample, and 0 otherwise. Thus, the inverse log of $\hat{\gamma}_{j}\left(e^{\hat{\gamma}_{j}}\right)$ is an estimate of the proportional default risk premium on day $j$ relative to that on Mar. 1, 2006 (the reference time period). $\Delta \mathrm{RP}$ is the daily change in $e^{\hat{\gamma}_{j}}$.

Finally, I project changes in the risk premium onto Lehman Brothers (Barclays) AAA-CCC bond index returns to avoid explaining CDS spreads with CDS spreads. The results are robust to this last step. This yields the final measure $\Delta R P$, which is used in the second-stage regressions.

\section{Risk Premium Robustness Variables}

SAB The size of the asset-backed commercial paper market from the St. Louis Federal Reserve. This is the total principal (in billions) outstanding in the asset-backed commercial paper market each week (Wednesday).

Financial institutions relied heavily on asset-backed commercial paper to fund their daily operations, especially in the years leading up to the crisis. Therefore, changes in the total size of the market may reflect changes in the aggregate pool of capital available to fund financial institutions. Hence, this may be a useful measure of funding liquidity.

FAIL The aggregate amount of corporate fixed-income collateral (in millions) that counterparties failed to deliver on repurchase (repo) transactions each week obtained from the New York Federal Reserve. These failures are costly for financial institutions because they incur penalties. Therefore, counterparties may fail to deliver when it is difficult or costly to purchase the appropriate collateral. As a result, failures are likely correlated with bond market liquidity.

NDF Net dealer funding from the New York Federal Reserve. This is the total amount of securities lent less the total amount of securities borrowed (in millions) each week by primary dealers. It gives a measure of the net funding obtained by primary dealers through securities transactions. Adrian and Fleming (2005) argue that net dealer funding proxies for dealer leverage. Adrian et al. (2013) show that dealer leverage is priced in the cross section of stock returns because it captures dealer funding constraints. Therefore, NDF likely contains useful information about dealer funding liquidity.

VIX The implied volatility index for the S\&P 500 return from the Chicago Mercantile Exchange. The VIX index has been used in numerous studies to measure investors' risk aversion. I use the Wednesday level to represent weekly VIX.

ABX The weekly return on the AAA tranche of the ABX.HE index from Markit. The $\mathrm{ABX}$ index was commonly used as a benchmark for mark-to-market valuation of subprime mortgage portfolios and mortgage-backed securities in the crisis. Therefore, it may provide information about large losses at financial institutions. I focus on the AAA tranche because it was likely the most widely held by financial institutions.

Premiums on the ABX are quoted as an upfront spread. Therefore, I calculate returns as a simple percentage change between weekly (Wednesday) observations. 


\section{References}

Acharya, V., and T. C. Johnson. "Insider Trading in Credit Derivatives." Journal of Financial Economics, 84 (2007), 110-141.

Acharya, V.; S. Schaefer; and Y. Zhang. "Liquidity Risk and Correlation Risk: A Clinical Study of the General Motors and Ford Downgrade of May 2005." Quarterly Journal of Finance, 5 (2015), $1-51$.

Adrian, T.; E. Etula; and T. Muir. "Financial Intermediaries and the Cross-Section of Asset Returns." Journal of Finance, 69 (2013), 1540-6261.

Adrian, T., and M. Fleming. "What Financing Data Reveal about Dealer Leverage." Current Issues in Economics and Finance, 11 (2005).

Aitkin, M. "Correlation in a Singly Truncated Bivariate Normal Distribution." Psychometrika, 29 (1964), 263-270.

Allen, L., and A. Saunders. "A Survey of Cyclical Effects in Credit Risk Measurement Models." Working Paper, Bank of International Settlement (2003).

Arora, N.; P. Gandhi; and F. A. Longstaff. "Counterparty Credit Risk and the Credit Default Swap Market.” Journal of Financial Economics, 103 (2012), 280-293.

Azizpour, S.; K. Giesecke; and B. Kim. "Premia for Correlated Default Risk." Journal of Economic Dynamics and Control, 35 (2011), 1340-1357.

Baker, M., and J. Wurgler. "Market Timing and Capital Structure." Journal of Finance, 57 (2002), $1-32$.

Bao, J., and J. Pan. "Bond Illiquidity and Excess Volatility." Review of Financial Studies, 26 (2013), 3068-3103.

Bekaert, G.; C. Harvey; and A. Ng. "Market Integration and Contagion.” Journal of Business, 78 (2005), 39-69.

Bekaert, G.; R. J. Hodrick; and X. Zhang. "International Stock Return Comovements.” Journal of Finance, 64 (2009), 2591-2626.

Ben-David, I.; F. Franzoni; and R. Moussawi. "Hedge Fund Stock Trading in the Financial Crisis of 2007-2009.” Review of Financial Studies, 25 (2012), 1-54.

Berndt, A.; R. Douglas; J. D. Duffie; M. Ferguson; and D. Schranz. "Measuring Default Risk Premia from Default Swap Rates and EDFs.” Working Paper, Bank of International Settlement (2008).

Blanco, R.; S. Brennan; and I. Marsh. "An Empirical Analysis of the Dynamic Relation between Investment-Grade Bonds and Credit Default Swaps.” Journal of Finance, 60 (2005), 2255-2281.

Bongaerts, D.; F. de Jong; and J. Driessen. "Derivative Pricing with Liquidity Risk: Theory and Evidence from the Credit Default Swap Market.” Journal of Finance, 66 (2011), 203-240.

Brunnermeier, M. K. “Deciphering the Liquidity and Credit Crunch 2007-2008." Journal of Economic Perspectives, 23 (2009), 77-100.

Brunnermeier, M. K., and L. H. Pedersen. "Market Liquidity and Funding Liquidity." Review of Financial Studies, 22 (2009), 2201-2238.

Campbell, J. Y.; J. Hilscher; and J. Szilagyi. "In Search of Distress Risk." Journal of Finance, 63 (2008), 2899-2939.

Campbell, J. Y., and G. B. Taksler. "Equity Volatility and Corporate Bond Yields.” Journal of Finance, 58 (2003), 2321-2349.

Casey, O., and T. Price. "The CDS Big Bang: Understanding the Changes to the Global CDS Contract and North American Conventions." Markit Research Report (2009).

Chen, L.; D. A. Lesmond; and J. Wei. "Corporate Yield Spreads and Bond Liquidity." Journal of Finance, 62 (2007), 119-149.

Christoffersen, P.; K. Jacobs; X. Jin; and H. Langlois. "Dynamic Dependence in Corporate Credit." Working Paper, University of Toronto (2016).

Collin-Dufresne, P.; R. Goldstein; and S. Martin. "The Determinants of Credit Spread Changes." Journal of Finance, 56 (2001), 2177-2207.

Crosbie, P., and J. Bohn. "Modeling Default Risk." Moody's KMV Report (2003).

Donner, A., and G. Zou. "Testing the Equality of Dependent Intraclass Correlation Coefficients." Journal of the Royal Statistical Society Series D: The Statistician, 51 (2002), 367-379.

Driessen, J. "Is Default Event Risk Priced in Corporate Bonds?" Review of Financial Studies, 18 (2005), 165-195.

Duffie, D. "Innovations in Credit Risk Transfer: Implications for Financial Stability." Working Paper, Bank of International Settlement (2008). 
Duffie, D.; A. Eckner; G. Horel; and L. Saita. "Frailty Correlated Default." Journal of Finance, 64 (2009), 2089-2123.

Eichengreen, B.; A. Mody; M. Nedeljkovic; and L. Sarno. "How the Subprime Crisis Went Global: Evidence from Bank Credit Default Swap Spreads." Journal of International Money and Finance, 31 (2012), 1299-1318.

Elton, E.; M. Gruber; D. Agrawal; and C. Mann. "Explaining the Rate Spread on Corporate Bonds." Journal of Finance, 56 (2001), 247-277.

Ericsson, J.; K. Jacobs; and R. Oviedo. "The Determinants of Credit Default Swap Premia." Journal of Financial and Quantitative Analysis, 44 (2009), 109-132.

Fama, E., and K. French. "The Cross-Section of Expected Stock Returns." Journal of Finance, 47 (1992), 427-465.

Fama, E., and K. French. "Common Risk Factors in the Returns on Stocks and Bonds." Journal of Financial Economics, 33 (1993), 3-56.

Ferson, W. E., and C. R. Harvey. "The Variation of Economic Risk Premiums." Journal of Political Economy, 99 (1991), 385-415.

Fleming, M. "Measuring Treasury Market Liquidity." Federal Reserve Bank of New York Economic Policy Review, 9 (2003), 83-108.

Frazzini, A., and L. H. Pedersen. "Betting against Beta." Journal of Financial Economics, 111 (2013), $1-25$.

Gilchrist, S., and E. Zakrajsek. "Credit Spreads and Business Cycle Fluctuations." American Economic Review, 102 (2012), 1692-1720.

He, Z., and A. Krishnamurthy. "A Model of Capital and Crises." Review of Economic Studies, 79 (2012), 735-777.

Jarrow, R.; D. Lando; and F. Yu. "Default Risk and Diversification: Theory and Empirical Implications." Mathematical Finance, 15 (2005), 1-26.

Jorion, P., and G. Zhang. "Good and Bad Credit Contagion: Evidence from Credit Default Swaps." Journal of Financial Economics, 84 (2007), 860-883.

Jorion, P., and G. Zhang. "Credit Contagion from Counterparty Risk.” Journal of Finance, 64 (2009), 2053-2087.

Kallberg, J., and P. Pasquariello. "Time-Series and Cross-Sectional Excess Comovement in Stock Indexes." Journal of Empirical Finance, 15 (2008), 481-502.

Kandel, S., and R. F. Stambaugh. "On the Predictability of Stock Returns: An Asset-Allocation Perspective." Journal of Finance, 51 (1996), 385-424.

Kealhofer, S. "Quantifying Credit Risk I: Default Prediction.” Financial Analysts Journal, 59 (2003), $30-44$.

Kim, D. H.; M. Loretan; and E. M. Remolona. "Contagion and Risk Premia in the Amplification of Crisis: Evidence from Asian Names in the Global CDS Market." Journal of Asian Economics, 21 (2010), 314-326.

Liu, J.; F. A. Longstaff; and R. E. Mandell. "The Market Price of Risk in Interest Rate Swaps: The Roles of Default and Liquidity Risks." Journal of Business, 79 (2006), 2337-2359.

Longstaff, F. A. "The Subprime Credit Crisis and Contagion in Financial Markets." Journal of Financial Economics, 97 (2010), 436-450.

Merton, R. C. "On the Pricing of Corporate Debt: The Risk Structure of Interest Rates." Journal of Finance, 29 (1974), 449-470.

Mitchell, M.; L. H. Pedersen; and T. Pulvino. "Slow-Moving Capital." American Economic Review, 97 (2007), 215-220.

Mitchell, M., and T. Pulvino. "Arbitrage Crashes and the Speed of Capital." Journal of Financial Economics, 104 (2012), 469-490.

Morck, R.; B. Yeung; and W. Yu. "The Information Content of Stock Markets: Why Do Emerging Markets Have Synchronous Stock Price Movements?" Journal of Financial Economics, 58 (2000), 215-260.

Pástor, V., and R. Stambaugh. "Liquidity Risk and Expected Stock Returns." Journal of Political Economy, 111 (2003), 642-685.

$\mathrm{Pu}, \mathrm{X}$. "Liquidity Commonality across the Bond and CDS Markets." Journal of Fixed Income, 19 (2009), 26-39.

$\mathrm{Pu}, \mathrm{X}$. , and X. Zhao. "Correlation in Credit Risk Changes." Journal of Banking and Finance, 36 (2012), 1093-1106.

Schaefer, S. M., and I. A. Strebulaev. "Structural Models of Credit Risk Are Useful: Evidence from Hedge Ratios on Corporate Bonds." Journal of Financial Economics, 90 (2008), 1-19. 
Schucany, W. R., and W. H. Frawley. “A Rank Test for Two-Group Concordance.” Psychometrika, 38 (1973), 249-258.

Stanton, R., and N. Wallace. "The Bear's Lair: Index Credit Default Swaps and the Subprime Mortgage Crisis." Review of Financial Studies, 24 (2011), 3250-3280.

Tang, D., and H. Yan. "Liquidity and Credit Default Swap Spreads." Working Paper, University of Hong Kong (2008).

Vassalou, M., and Y. Xing. “Default Risk in Equity Returns.” Journal of Finance, 59 (2004), 831-868. 